IZA DP No. 9303

The Cost-Effectiveness of Developmental Screenings:

Evidence from a Nationwide Programme

Martin Halla

Gerald Pruckner

Thomas Schober

August 2015

Forschungsinstitut

zur Zukunft der Arbeit

Institute for the Study

of Labor 


\title{
The Cost-Effectiveness of Developmental Screenings: Evidence from a Nationwide Programme
}

\author{
Martin Halla \\ University of Innsbruck, \\ CDECON and IZA \\ Gerald Pruckner \\ CDECON, Johannes Kepler University Linz \\ Thomas Schober \\ CDECON, Johannes Kepler University Linz
}

Discussion Paper No. 9303

August 2015

IZA

P.O. Box 7240

53072 Bonn

Germany

Phone: +49-228-3894-0

Fax: +49-228-3894-180

E-mail: iza@iza.org

\begin{abstract}
Any opinions expressed here are those of the author(s) and not those of IZA. Research published in this series may include views on policy, but the institute itself takes no institutional policy positions. The IZA research network is committed to the IZA Guiding Principles of Research Integrity.

The Institute for the Study of Labor (IZA) in Bonn is a local and virtual international research center and a place of communication between science, politics and business. IZA is an independent nonprofit organization supported by Deutsche Post Foundation. The center is associated with the University of Bonn and offers a stimulating research environment through its international network, workshops and conferences, data service, project support, research visits and doctoral program. IZA engages in (i) original and internationally competitive research in all fields of labor economics, (ii) development of policy concepts, and (iii) dissemination of research results and concepts to the interested public.
\end{abstract}

IZA Discussion Papers often represent preliminary work and are circulated to encourage discussion. Citation of such a paper should account for its provisional character. A revised version may be available directly from the author. 


\title{
ABSTRACT \\ The Cost-Effectiveness of Developmental Screenings: Evidence from a Nationwide Programme*
}

\begin{abstract}
Early intervention is considered the optimal response to developmental disorders in children. We evaluate a nationwide developmental screening programme for preschoolers in Austria and the resulting interventions. Identification of treatment effects is determined by a birthday cutoff-based discontinuity in the eligibility for a financial incentive to participate in the screening. Assigned preschoolers are about 14 percentage points more likely to participate in the programme. For participants with high socio-economic status (SES), we find little evidence for interventions and consistently no effect on healthcare costs in the long run. For participants with low SES preschoolers, we find evidence for substantial interventions, but only weak evidence for cost savings in the long run.
\end{abstract}

JEL Classification: I12, J13, I18, H51, H75

Keywords: early intervention, child development, developmental disorder, developmental screening, healthcare costs

Corresponding author:

Martin Halla

University of Innsbruck

Department of Public Finance

Universitätstraße 15

6020 Innsbruck

Austria

E-mail: martin.halla@uibk.ac.at

\footnotetext{
* For helpful discussions and comments we would like to thank the participants of the NRN research seminar 'Labor Economics and the Welfare State' in Vienna, the DEEP Advanced Seminar in Economics at the University of Lausanne, the 2015 Annual Conference of the European Society for Population Economics in Izmir (Turkey), and the IWQW Research Seminar at the University of Erlangen-Nuremberg. The usual disclaimer applies. We gratefully acknowledge financial support from the Austrian Science Fund (FWF) under the National Research Network 'The Austrian Center for Labor Economics and the Analysis of the Welfare State', project no. S10306-G16, and the Christian Doppler Research Association (CDG).
} 


\section{Introduction}

A growing body of literature across different academic disciplines traces the origins of life-cycle well-being to the very early stages of life (Currie and Rossin-Slater, 2015). One important aspect is early-life health. A variety of policies, such as prenatal care, family leave, nurse home visiting, or early childhood centre-based interventions, have the potential to improve health conditions at different stages of early childhood. In this study, we are concerned with medical care interventions for preschoolers with respect to developmental disorders. We are particularly interested in the identification of affected preschoolers, a step that predates any diagnosis or treatment.

An estimated 14 percent of all children in the US have some form of developmental disorder (Boyle et al., 2011). There is widespread agreement among medical specialists and policy-makers that early identification of developmental disorders in children is essential for optimal intervention. ${ }^{1}$ Developmental disorders, or delayed development, can be caused by specific medical conditions and may indicate an increased risk of other medical complications, as well as emotional and behavioural disorders. Early identification of developmental problems enables further evaluation, diagnosis, and treatment (Chakrabarti and Fombonne, 2001).

Successful intervention improves the well-being of families with affected children. If affected families are predominately from lower socio-economic status (SES), such early intervention can be perceived as socially fair, since it helps to reduce (health) inequalities. The economic efficiency-based argument for early intervention rests on the simple comparison between the costs of intervention (today) and the costs of non-intervention (later). Proponents typically assume that early intervention is more cost-effective than later remediation (Conti and Heckman, 2013).

While these theoretical arguments make a compelling case for early intervention, they do not provide guidance on how to implement intervention. In practice, a crucial point is the identification of developmental disorders that predate any diagnosis or treatment. Typically, developmental screening programs are used. For instance, the American Academy of Pediatrics officially recommends that a standardized developmental screening test should be administered regularly at the ages of 9,18 , and 30 months. ${ }^{2}$ Depending on age, these screening tests inspect the development of motor skills and co-ordination, visual and hearing abilities, communication and language skills, and cognitive abilities.

\footnotetext{
${ }^{1}$ This view is in line with a growing body of literature pointing to the importance of early childhood in building the foundations for lifelong health. David J. Barker (see, for instance, Barker, 1995) developed the argument that the prenatal environment affects health conditions in adulthood, including heart disease and diabetes. Equivalent reasoning is documented in the literature on human capital, in which the substantial benefit from early interventions arises because human capital formation is dynamic in nature (Cunha and Heckman, 2007; Almond and Currie, 2011).

${ }^{2}$ See Council on Children With Disabilities, Section on Developmental Behavioral Pediatrics, Bright Futures Steering Committee and Medical Home Initiatives for Children With Special Needs Project Advisory Committee (2006) and reaffirmation for this policy in American Academy of Pediatrics (2010).
} 
Ideally, a screening identifies all developmental disorders in these dimensions and initiates a comprehensive and purposeful response. However, little is known about the (cost-) effectiveness of developmental screenings in practice.

Even if it seems obvious that early intervention is desirable and most likely efficient, the literature has paid insufficient attention to the identification of developmental disorders and associated costs. In this study, we are interested in not only the intervention, but also the screening process that precedes any intervention. Depending on the context, the costs of identifying developmental disorders may vary strongly.

We evaluate a nationwide developmental screening programme of preschoolers and subsequent medical interventions in Austria. Austria is a high-income country with a Bismarckian healthcare system offering a prenatal and early postnatal healthcare programme that is free of charge and fully financially incentivized. In a subsequent developmental screening programme, parents are offered examinations for their children, inter alia, at the ages of 24, 36, and 48 months. Parents may consult any contracted paediatrician or general practitioner (GP) who executes a predefined age-specific developmental screening procedure. This comprises physical examinations, assessment of a child's mental development, and identification of behavioural problems. In case of any abnormal results, the doctor will either schedule a follow-up appointment or refer the child to other professionals. The developmental screening itself and any follow-up appointment are fully covered by statutory health insurance.

In 2000, one provincial government (Upper Austria) introduced a financial incentive to promote developmental screening participation. Irrespective of their household income, families are offered $€ 185$ if their child participates in all three screenings, including some stipulated vaccinations. The only eligibility criterion is that the child was born on 1 January 2000 or later. We exploit this sharp birthday cutoff-based discontinuity in the eligibility to obtain exogenous variation in participation. We find that assigned preschoolers are-irrespective of their SES-14 percentage points more likely to be screened.

To assess the cost-effectiveness of this screening programme, we use high-quality administrative data. These provide information on the scope of intervention and long-term healthcare costs. The scope of intervention is quantified by short-run healthcare expenditure for follow-up treatments by the screening doctors and referrals to other specialists. If screening participation increases the likelihood of identifying a disorder, we expect an increase in short-run follow-up expenditure, compared to the counter-factual situation of non-participation. For a programme to be cost-effective, savings in the long run need to exceed the increase in expenditure due to early intervention. We observe the healthcare spending for preschoolers up to 11 years of age. Since we do not observe any direct measures of preschoolers' well-being, we cannot provide a comprehensive welfare-based cost-benefit analysis.

Based on a fuzzy regression discontinuity design, we find that the programme is clearly 
not cost-effective for preschoolers with higher SES, who comprise about 75 percent of the total preschooler population. For this group, we obtain a consistent picture with little evidence for interventions (the only exception is follow-up examinations by ophthalmologists), and consequently, no effect on healthcare costs in the long run. For low SES preschoolers, who comprise about 25 percent of the total preschooler population, the interpretation is less clear. While we find clear evidence for interventions with follow-up examinations by several medical specialists, there is only weak evidence for cost savings in the long run. As an alternative interpretation, we consider the increase in healthcare expenditure in the short run not as an intervention addressing developmental disorders, but as supply-induced over-treatment resulting from profit-maximizing screening doctors. An additional estimation analysis focusing on 'referred' follow-up examinations, without any financial benefit for the screening doctors, provides evidence that at least part of the increase in short-run healthcare expenditure is due to justified interventions.

These results have to be interpreted in the context of the Austrian healthcare system. There are financial incentives for health screenings up to the second year of life and participation rates are high (see below). Moreover, parents can always consult medical specialists independently of participation in the programme and free of charge. We consider our results to be representative of a European welfare state, for which we conclude that physician-based developmental screenings for preschoolers should be promoted only among preschoolers with lower SES.

The remainder of this paper is organized as follows. In Section 2, we briefly outline the theoretical determinants of the effectiveness of developmental screening programmes. In Section 3, we summarize the related literature. In Section 4, we present our research design. In Section 5, we present our estimation results along with several robustness checks. In Section 6, we provide an overall assessment of our estimation results. Finally, Section 7 formulates policy recommendations and concludes.

\section{Theoretical Determinants of Developmental Screen- ing Cost-Effectiveness}

From a theoretical point of view, a necessary condition for a cost-effective intervention is that the screening programme identifies any developmental disorders that can be treated. Thus, if the subjects have no or only non-treatable disorders, the intervention is bound to fail (Case 1). Similarly, if treatable disorders exist but are not identified, then the intervention would certainly be ineffective (Case 2).

Assuming that the screening programme identifies treatable disorders, the outcome in the counter-factual situation is decisive. It is possible that the disorder would have been diagnosed and treated without any screening (Case 3). For instance, proactive parents 
could have consulted a paediatrician anyway. In this case, the timing is relevant. If the screening caused an earlier treatment that would have improved the child's well-being and potentially reduced future healthcare costs, then the intervention could be cost-effective. If the screening caused no (or no beneficial) earlier treatment, we would consider it as ineffective; resources would have been wasted on subjects without any disorders. The final case of a potentially effective screening is provided: if disorders would not have been diagnosed in the counter-factual situation without any screening (Case 4).

In Cases 3 and 4, in which screening leads to an (earlier) treatment of a disorder, cost-effectiveness would require that long-run costs decreases outweigh the increases in short-term treatment costs, including those for the screening itself. The screening costs should not only cover direct out-of-pocket expenditure, but also incorporate potential harm or considerable discomfort caused by the screening procedure itself, as well as any costs due to false positive outcomes that result in anxiety and/or over-treatment. In addition, costs should account for any follow-up medical examinations that are triggered by the screening. Screening-performing doctors may conduct further examinations or refer preschoolers to specialists for more detailed diagnostic services. The likelihood of further examinations increases with the doctor's level of risk aversion and decreases with his or her expertise and experience. Moreover, depending on the institutional setting, it cannot be ruled out that some further examinations are not justified medically. If screeningperforming doctors financially benefit from further examinations, supply-induced demand may lead to unnecessary follow-up examinations.

Thus, it is ultimately an empirical question whether a certain developmental screening programme is effective. Nonetheless, we can conclude that a developmental screening programme is more likely to be effective,

- if it focuses on subjects who are likely to have easily identifiable and treatable disorders,

- if untreated disorders cause substantial costs for the patient and society,

- if disorders remain most likely undetected for a long time in the counter-factual situation without screening, and

- if screening costs are low.

- Screening costs are expected to be low if performing doctors are specialized and experienced, and have no financial interest in further examinations.

\section{Related Literature}

Thus far, the literature has not provided rigorous evaluation of physician-based developmental screenings for preschoolers. This is especially surprising given the extensive 
recommendations made by professional organizations and government agencies. Moyer and Butler (2004) conduct a systematic review of the literature for any paediatricianbased developmental screening and conclude that methodologically sound randomized controlled trials (RCTs) of developmental screenings do not exist. A more recent systematic review focussing on vision screening (Chou et al., 2011) concludes that no RCT exists that compares the effect of screening with non-screening. ${ }^{3}$ Cadman et al. (1987) is the only exception we are aware of. Based on a RCT, the authors evaluate the effectiveness of a screening programme for 4- to 5-year old children, which includes general health interviews, and hearing and vision tests administered by public health nurses. Three years after the screening, they could not detect any effect of the intervention on developmental attainment or school performance.

In contrast to screening activities in the physician's office, there is substantial evidence on the effectiveness of two related types of programmes: home visit programmes and more comprehensive centre-based preschool interventions. Both types of interventions typically focus on children at risk because of low parental income or other adverse social circumstances and often comprise a developmental screening component.

In home visit programmes, trained professionals, such as nurses or para-professionals, provide services for pregnant women and families with young children in their own homes. These programmes aim to improve child health and development, for example, by educating and coaching families in areas of parenting, nutrition, well-child care, immunizations, and appropriate care for illnesses and injuries. Recent meta analyses of RCTs show that home visit programmes in general have beneficial effects on participating families, including cognitive and social child development, prevention of child abuse, and reduction of health problems (Sweet and Appelbaum, 2004; Peacock et al., 2013; Avellar and Supplee, 2013).

Preschool interventions studied in the literature are mostly US programmes that are centre-based interventions focussing on education. Thus, it is hard to disentangle the effect of any developmental screening component. For instance, the Carolina Abecedarian Project consisted of a full-day child care setting in which children participated in a systematic curriculum to enhance the development of skills in cognition, language, and adaptive behaviour, but also received their primary medical care on site (Campbell and Ramey, 1994). A meta analysis by Duncan and Magnuson (2013) shows that this type of preschool intervention improves child outcomes in many dimensions, although the distribution of impact estimates is extremely dispersed. While gains in achievement tests tend to fade over time, beneficial impacts on long-term outcomes, such as educational attain-

\footnotetext{
${ }^{3}$ Williams et al. (2002) compare more intensive to less intensive screening. They focus on the detection and early treatment of amblyopia. The control group was assigned to a single intensive orthoptic screening at 37 months of age. The treatment group was screened five times (at 8,12, 18, 25, and 37 months of age). The main result is that amblyopia was significantly less prevalent among the treatment group at the age of 7.5 years.
} 
ment, teen parenthood, and criminality have been documented. Considering effects on health, Campbell et al. (2014) follow the Carolina Abecedarian Project participants up to their mid-30s and show that the programme significantly promotes adult health. Treated individuals have a lower prevalence of risk factors for cardiovascular and metabolic diseases, which are derived from measurements of blood pressure, cholesterol, and obesity levels. Similarly, Carneiro and Ginja (2014) show that Head Start-the largest federal preschool programme in the US-decreases health problems among children and lowers depression and obesity among adolescents.

\section{Research Design}

In this section, we first describe the institutional background, including the details of the developmental screening programme and the financial incentives for participation in Upper Austria. Then, we present our data sources and estimation strategy, and discuss the identifying assumptions.

\subsection{Institutional Background}

Austria has a Bismarckian welfare system with almost universal access to high-quality healthcare. Insurance is compulsory and, in general, is linked to employment. Our data cover private-sector employees (about 75 percent of the population) who are, depending on the type and location of the employer, insured with one of nine regional health insurance funds (in German, Gebietskrankenkassen). ${ }^{4}$ Thus, workers have no choice regarding their healthcare provider or insurance package.

The outpatient healthcare system is funded predominantly by wage-related social security contributions of employers and employees. ${ }^{5}$ Health insurance contributions increase proportionally with income up to a ceiling, but are independent of the personal risk of the insured. The health insurance funds cover all healthcare expenditure in the inpatient and outpatient sector, including maternity and the institutionalized mother-child screening programme.

The Organisation for Economic Co-operation and Development (OECD) concludes that the Austrian healthcare system delivers good quality and easily accessible services, albeit at very high costs (Gönenc et al., 2011). ${ }^{6}$ The extensive provision of care with

\footnotetext{
${ }^{4}$ Non-employed individuals are also covered by the regional health insurance funds. Farmers, other self-employed people, civil servants, and employees of the Austrian Railway Company and the mining industry have their own nationwide health insurance institutions. Moreover, there are six companyspecific health insurance funds.

${ }^{5}$ The inpatient sector is co-financed by social security contributions and general tax revenues from different federal levels.

${ }^{6}$ Both the life expectancy and per capita of total health spending are above the OECD average. Infant mortality is below the OECD average; however, it is significantly higher compared to Scandinavian countries.
} 
wide patient choice among in- and outpatient providers (i.e. there is no strict gatekeeping) combined with fee-for-service remuneration of doctors tends to produce high volumes of services. It is argued that the governance and funding structure is highly fragmented and over-uses expensive inpatient healthcare services. In summary, the system predominantly operates on a supply-driven basis and does not have clear mechanisms to optimize spending on a cost-benefit or cost-effectiveness basis.

\subsubsection{Mother-Child-Pass Examination Programme}

Public prenatal care has been established in Austria for decades. In 1974, the Austrian Federal Ministry of Health launched the first nationwide prenatal screening programme. ${ }^{7}$ This so-called Mother-Child-Pass Examination Programme (MCPEP) consisted initially of four prenatal examinations. Over time, the aim and scope of the MCPEP has expanded substantially. Currently, it is a comprehensive screening programme that monitors the health of expectant mothers and their children over about 70 months. It starts with the first diagnosis of pregnancy (ideally before the 16th week) and lasts until the 5th year of the child's life. In total, it comprises five prenatal examinations, five postnatal examinations of infants (up to 14 months), and three developmental screenings of toddlers and preschoolers (from 24 to 48 months). Table 1 summarizes the timeframe, type, and incentive structure for all examinations. Our focus is on the three developmental screenings (D1 to D3), which we discuss in more detail below. All stipulated examinations are free of charge, even for mothers without social health insurance coverage. Generally, the examinations are provided by resident gynaecologists, paediatricians, and GPs. ${ }^{8}$

As part of the programme, expectant mothers receive the so-called mother-child pass (in German, Mutter-Kind-Pass). This official document issued by the Austrian Federal Ministry of Health is a booklet documenting all examinations and their results. In addition, expectant mothers receive an international certificate of vaccination for their child, and an additional information booklet containing advice on a variety of relevant topics. This documentation is important for mothers, not least owing to the fact that participation in the programme is a prerequisite for receipt of financial payments.

Financial Incentives for Programme Participation Participation in the MCPEP traditionally has been financially incentivized on a federal level. However, the subsidy has never applied to the developmental screening part of the programme (D1, D2, and

\footnotetext{
${ }^{7}$ At the time this programme was launched, infant mortality was comparably high in Austria. It amounted to 24 deaths of infants under the age of 1 year per 1,000 live births. This was somewhat above the US figures. Since then, infant mortality rates have declined continuously, and are currently well below the US rates (own calculations based on data from the World Bank).

${ }^{8}$ For risk pregnancies, hospitals provide selected services related to prenatal diagnostics. In general, the first postnatal check-up is conducted in the same hospital immediately after birth. Moreover, in the case of complications, both the mother and child are always referred to the hospital for follow-up examinations that are beyond the scope of the MCPEP.
} 
D3). Mothers receive financial transfers if they have participated in the five prenatal and five postnatal examinations of infants up to 14 months (see column four of Table 1). The specific regulations have varied over time. For our empirical analysis, the period from 1997 through 2001 is mostly relevant, when each eligible mother who participated in the five prenatal and five postnatal examinations of infants up to 14 months received a one-time payment of $€ 145$.

\subsubsection{Developmental Screening Programme}

Although the development screening part of the MCPEP (D1, D2, and D3) has never been incentivized on a federal level, the Upper Austrian provincial government introduced a so-called mother-child (MC) subsidy (in German Mutter-Kind-Zuschuss) for all children born on 1 January 2000 or later. ${ }^{9}$ Eligible mothers received $€ 185$ if they participated in all three developmental screening examinations (D1, D2, and D3), including vaccinations. This regulation was enacted by the Upper Austrian government in November 2001. All mothers, irrespective of their household income, were eligible. The application had to be filed within 1 year after the 5th birthday of the child.

In our empirical analysis, we exploit this sharp discontinuity in eligibility by date of birth for the Upper Austrian MC subsidy. This creates a clear distinction between treated and control units. Mothers whose children were born before 1 January 2000 had no financial incentive to participate in D1, D2, and D3. By contrast, mothers whose children were born on 1 January 2000 or later (henceforth, 'assigned mothers') received $€ 185$. As we show below, assigned mothers are 14 percentage points more likely to participate in D1 to D3. ${ }^{10}$ Under very weak identifying assumptions (see below), this allows us to evaluate the effect of these preschool examinations on the subsequent health outcomes up to preadolescence.

In the examinations D1 to D3, the child's development is examined at the ages of about 24, 36, and 48 months. The examinations have a preventative character that promotes early detection and timely treatment of health risks. The examinations include an anamnesis that covers potential behavioural disorders, previous diseases, and the speech and language development of the child. In a physical examination, the doctor tests the child's ears and eyes and examines his or her teeth and organs. Furthermore, the child's

\footnotetext{
${ }^{9}$ Upper Austria is one of nine provinces in Austria. It comprises about one sixth of the Austrian population and workforce. It was the only federal state that offered a financial incentive.

${ }^{10}$ In support of the federal incentive, the Upper Austrian government offered another $€ 185$ to mothers whose children were born after 1 January 2000 if they participated in the five prenatal and five postnatal examinations of infants up to 14 months. Given that this regulation was not enacted before November 2001 , it has no impact on the evaluation of the developmental screenings. Since the age of the youngest child in our estimation sample was 19 months, he or she was too old for the mother to react to this incentive. The only potential confounding factor is an income effect. Children born after 1 January 2000 who participated in all stipulated examinations (without their mothers knowing that financial incentives would be introduced in the future) received ex post $€ 185$. We consider this amount to be too low to affect child health or children's volume of healthcare expenditure.
} 
weight, height, and head circumference are recorded and motor skills, nutritional status, and mental development are assessed. Furthermore, a comprehensive eye and vision examination is scheduled for D1, and measurements of blood pressure are scheduled for D2 and D3.

Parents can freely choose either a contracted paediatrician or a GP to conduct the screening. It turns out that parents, irrespective of their SES, predominantly choose paediatricians, who perform about two thirds of all screenings. Ophthalmologists carry out the eye examination part of the screenings. For D1 to D3, physicians receive a fixed payment of $€ 21.8$ per examination during the entire study period. This payment is worthwhile for the screening doctor given the reimbursement for a general consultation in the outpatient sector, which in 2011 , for example, was $€ 20.6$ on average.

\subsection{Data}

In our empirical analysis, we use administrative data from the Upper Austrian Health Insurance Fund. It covers the sub-population of all private sector employees and their dependants in the province of Upper Austria. These data include, among others, detailed information on healthcare service utilization in the outpatient sector (i.e. medical attendance and drug use) and some inpatient sector information (e.g. number of days of hospitalization). Thus, we observe participation in the examinations stipulated by the MCPEP, but also any other single-doctor visit and each drug prescription, together with the exact date of service utilization. Furthermore, we can trace the screening doctors' referral behaviour. It must be noted, however, that the Austrian outpatient sector does not impose a strict gate-keeping system. Even if health insurance funds strongly recommend a formal referral of a GP for any consultation of a medical specialist, each patient is allowed to visit one specialist per quarter in each medical field without written referral by the family doctor. ${ }^{11}$

We focus on children born between September 1999 and April 2000. We observe healthcare costs for all children up to 10.5 years of age. The latest year available in our dataset is 2011 and all expenditure is measured in 2011 euros. We complement these data with information from the Austrian Birth Register. This includes detailed information about the birth (for instance, gestational length and birth weight) and socio-economic information about the mother. We use this information to generate covariates for our regression analysis and to explore heterogeneous treatment effects in different sub-samples of the population.

\footnotetext{
${ }^{11}$ The consultation of radiologists and utilization of laboratory services are excluded from this regulation.
} 


\subsection{Estimation Strategy}

Our estimation strategy exploits variation in the probability of developmental screening participation of preschooler $i$ resulting from the birthdate $B_{i}$ cutoff-based discontinuity in the eligibility for a financial incentive for participation. In other words, children born shortly before the cutoff $\left(B_{i}<c\right)$ are less likely to be screened compared to children born shortly after the cutoff $\left(B_{i}>c\right)$. Since the probability of participation does not jump from zero to one at this birthday cutoff, this represents a fuzzy regression discontinuity design (RDD). The design can be translated into a two-stage least square setup, in which the birthday cutoff serves as an instrumental variable for treatment status.

In the first-stage equation, the dependent variable is the treatment status $S_{i}$. In our main specification, we define a binary indicator $S_{i}^{3}$, which is equal to one if preschooler $i$ participated in all three developmental screening examinations (D1, D2, and D3). The explanatory variable of primary interest is the instrumental variable $T_{i}$, which is equal to one if preschooler $i$ is born after 1 January 2000, and zero otherwise $\left(T_{i}=1\right.$ if $\left.B_{i}>c\right)$ :

$$
S_{i}^{3}=\alpha_{0}+\alpha_{1} T_{i}+\alpha_{2}\left(B_{i}-c\right)+\alpha_{3}\left(B_{i}-c\right) \times T_{i}+A \mathbf{X}_{i}+\epsilon_{i}
$$

Furthermore, we allow for a different linear monthly trend in participation before and after the birthday cutoff $\left.\left(\left(B_{i}-c\right),\left(B_{i}-c\right) \times T_{i}\right)\right)$ and control for a set of covariates $\left(\mathbf{X}_{i}\right)$, including information on the preschooler's parity, gestational length, birth weight, legitimacy of birth, and the mother's age, citizenship, and educational attainment. All covariates are measured at the time of birth. The parameter of primary interest is $\alpha_{1}$, which gives us the change in the likelihood of participation in the whole developmental screening programme, depending on the eligibility for the financial incentive.

In the second-stage equation, we regress our respective outcome variable $O_{i}$ on the predicted $\hat{S}_{i}^{3}$ screening participation from the first stage:

$$
O_{i}=\beta_{0}+\beta_{1} \hat{S}_{i}^{3}+\beta_{2}\left(B_{i}-c\right)+\beta_{3}\left(B_{i}-c\right) \times T_{i}+B \mathbf{X}_{i}+\mu_{i}
$$

To evaluate the cost-effectiveness of the developmental screening programme, we examine two outcome dimensions. First, to assess the scope of intervention, we examine subsequent days of hospitalization and short-run healthcare expenditure for follow-up treatments by the screening doctors or other medical specialists, and for medication. We aggregate different categories of expenditure (e.g. for different types of resident medical specialists) over the age range from 18 to 54 months of children's lives. Second, we measure healthcare expenditure in the long run, defined as the age range from 6 to 10.5 years of children's lives. ${ }^{12}$ The upper age limit of 10.5 years results from the fact that

\footnotetext{
${ }^{12}$ We exclude from the analysis children with extremely high expenditure for medication (above the 99.5 percentile in short- or long-term expenditure).
} 
the latest year available in our data is 2011. The lower age limit of 6 years is chosen against the background that we conceptually attempt to capture healthcare costs that do not comprise expenditure for intervention triggered by the screening. Given that the last screening exam, D3, takes place at the age of 4 years, we are confident that our measurements for long-run healthcare costs can be interpreted meaningfully as outcomes of screening participation (i.e. we implicitly assume that medical interventions do not last longer than 2 years.

In our main specification, we use data covering 4 months before and 4 months after the birthday cutoff date. Thus, we include all preschoolers born between September 1, 1999 and May 1, 2000. This results in a sample size of 4,788 observations. ${ }^{13}$

Identifying Assumptions Three conditions need to hold for $\hat{\beta}_{1}$ to be informative about the effects of screening participation. First, the eligibility for the financial incentive $T_{i}$ must predict participation in the screening. This condition is testable. Figure 1 shows the first-stage relationship. Using birthdate, it plots the average share of preschoolers who have undergone all three screening examinations (referring to the binary treatment variable $S_{i}^{3}$ in our main specification). As expected, we observe a distinctive jump in the participation rate at the cutoff that can be attributed to the eligibility for the financial incentive. In other words, the probability of treatment is significantly higher for all eligible preschoolers. We show below that this condition also holds in a regression framework. Second, families do not precisely manipulate their children's dates of birth around the eligibility cutoff. This is the key identifying assumption behind any RDD. Since the Upper Austrian government enacted the financial incentive in retrospect on November 12, 2001, this assumption holds by definition. Accordingly, Figure 2 shows that the average number of births per day do not vary around the cutoff date. ${ }^{14}$

Third, eligibility must not be correlated with any outcome-determining factor. We start by examining some observable characteristics. Figure 3 shows that parity, legitimacy, mother's citizenship, and mother's educational attainment do not change discontinuously around the cutoff. The same holds true for any other predetermined characteristics we observe. Thus, we again have no reason to expect a correlation between eligibility and any unobserved outcome-determining factor (included in $\mu_{i}$ ).

To check the robustness of our estimation procedure, we estimate two alternative specifications. First, we estimate (as described above) equations (1) and (2) covering the 4 months before and 4 months after the cutoff. Second, we pool information from the previous turn of the year to account for any unobserved characteristics that follow a seasonal

\footnotetext{
${ }^{13}$ Our estimation results are not sensitive to the choice of the window width. Estimations based on a larger window (6 months) are very comparable to those obtained by the main specification.

${ }^{14}$ More formally, the density-based test suggested by McCrary (2008) confirms this. We cannot reject the hypothesis that there is a shift in the discontinuity at the birthday cutoff: test statistic $=0.023$, standard error $=0.102$ (bin size $=1$, default bandwidth calculation, bandwidth $=47.670$ ).
} 
pattern. ${ }^{15}$ Thus, we use information on all births between September 1998 through April 1999, and September 1999 through April 2000, resulting in 9, 516 observations. Now, we can include a series of binary indicators $M_{i, j}$ that capture the calendar month $j$ of the child's birth to control for month fixed effects:

$$
\begin{aligned}
& S_{i}^{3}=\gamma_{0}+\gamma_{1} T_{i}+\sum_{j=2}^{8} \gamma_{j} M_{i, j}+\gamma_{9} P_{i}+\Gamma \mathbf{X}_{i}+\eta_{i} . \\
& O_{i}=\delta_{0}+\delta_{1} \hat{S}_{i}^{3}+\sum_{j=2}^{8} \delta_{j} M_{i, j}+\delta_{9} P_{i}+\Delta \mathbf{X}_{i}+\nu_{i} .
\end{aligned}
$$

In addition, the binary variable $P_{i}$ captures whether the preschooler $i$ was born between September 1998 and April 1999 or between September 1999 and April 2000.

Moreover, we replicate all estimations with alternative treatment measurements. First, we define a binary indicator $S_{i}^{2,3}$ equal to one if the preschooler has participated in at least two of the screening examinations. Second, we define $S_{i}^{a b s}$ (where $S_{i}^{a b s} \in\{0,1,2,3\}$ ), capturing the absolute number of screening examinations in which the preschooler has participated.

\section{Estimation Results}

We present our estimation results in three steps. First, we discuss the effects of the eligibility for financial incentives on screening participation. Second, we examine the effects of participation on the scope of intervention. Third, we consider the effect of participation on long-run healthcare costs. We conclude this section with an overall assessment of our results.

\subsection{Effect of Financial Incentives on Participation}

The regression results summarized in Table 2 fully confirm the results suggested by Figure 1. Across all specifications, we find that the probability of treatment is significantly higher for eligible preschoolers (i.e. all children born on 1 January 2000 or later). Columns (1) to (3) are based on specification (1), which allows for different linear trends before and after the cutoff date. The coefficients indicate that the eligibility for the financial incentive $\left(T_{i}\right)$ increases the likelihood of participating in all three examinations by 14.7 percentage points, the probability of participation in two or more examinations by 16.4 percentage points, and the absolute number of performed exams by 0.38 . Columns (4) to (6) are

\footnotetext{
${ }^{15}$ There is some evidence in the US that children born at different times of the year are born to mothers with significantly different characteristics (Buckles and Hungerman, 2013). In fact, seasonality in unobserved characteristics would only constitute a threat to our identification if unobserved outcomedetermining factors varied discontinuously near the cutoff (December versus January).
} 
based on specification (3), which uses observations from children born 1 year earlier to control for birth month fixed effects. The estimated coefficients are very comparable and amount to 14.5 and 14.0 percentage points, respectively, and 0.36 additional screenings. Since the estimated effects are highly statistically significant in all six specifications (with large $F$ statistics), we can abstract from weak instrumental variable problems (Staiger and Stock, 1997). Notably, all estimated coefficients remain basically unchanged if we drop all further covariates. ${ }^{16}$ This supports the presumption that our instrumental variable $T_{i}$ is as good as randomly assigned.

To study whether families with different characteristics react differently to the financial incentive, we stratify our sample by different important dimensions measured at the time of birth. Most importantly, we use information on mother's educational attainment to proxy for the familiy's SES. We distinguish between low SES preschoolers (the mother has compulsory schooling or less, 25 percent) and higher SES preschoolers (mother has any degree higher than compulsory schooling, 75 percent). Further dimensions of sample splits are the mother's country of birth (Austria vs. foreign country), legitimacy of birth (mother is married vs. unmarried), and parity (first birth vs. higher order birth). Table 3 summarizes basic descriptive statistics and estimation results based on the month fixedeffects specification (3) using $S_{i}^{3}$ as a dependent variable. With one exception, we find very comparable effects of the financial incentive on screening participation between 13 and 16 percentage points. The respective F-statistics are at least 18. Foreign-born mothers are the only group that reacted to a lesser extent. Among them, eligible preschoolers were only 7.1 percentage points more likely to participate. A lack of language proficiency and institutional knowledge are plausible explanations for this finding. Since this estimated effect is only marginally significant and the resulting F-statistic is quite low, we do not consider second-stage results for this particular sample split.

\subsection{Effect of Participation on Scope of Intervention}

Our estimation results of the effect of the developmental screening on the scope of the intervention are summarized in Table $4 .{ }^{17}$ The outcome variables are aggregated over children's age period from 18 to 54 months and capture the costs for follow-up treatment excluding direct costs of the developmental screening. We present results for the overall sample, and for the two sub-samples of low and high SES preschoolers. It turns out that this is the only sample split providing heterogeneous second-stage results. ${ }^{18} \mathrm{In}$ the upper panel, we summarize the estimated effects on broad categories of healthcare

\footnotetext{
${ }^{16}$ The estimated coefficients of these simple ordinary least square regressions are as follows: (1) 0.145 , (2) 0.159, (3) 0.371, (4) 0.149 , (5) 0.145 , (6) 0.373 .

${ }^{17}$ We focus on second-stage estimation results based on the month fixed-effects specification (see equations (3) and (4)). Results based on the linear trends specification (see equations (1) and (2)) are very comparable and detailed estimation output is available upon request.

${ }^{18}$ Detailed estimation output for the other sub-samples is available upon request.
} 
expenditure: outpatient medical care, medication, and days in hospital. The lower panel provides results for expenditure for healthcare services at GPs and different types of resident medical specialists. For the overall sample, we list the reduced-form estimate (the intention-to-treat effect, ITT) and the second-stage estimate (the local average treatment effect, LATE). For the two sub-samples, we focus on the LATE. In each case, we list the sample mean of the respective outcome variable.

The first three columns show for the overall sample that screening participation does not trigger a statistically significant increase in aggregate follow-up expenditure for medical attendance in the outpatient sector. However, the disaggregated analysis (in the lower panel) reveals significantly positive effects on follow-up treatments provided by paediatricians and ophthalmologists. Paediatricians and ophthalmologists charge $€ 79.9$ and $€ 20.7$, respectively, for additional medical treatment following the developmental screening procedure, which correspond to approximately 80 percent and more than 100 percent, respectively, of the average expenditure. The statistically insignificant coefficients of expenditure for other medical specialists indicate that screening participation does not trigger follow-up referrals to doctors in other medical fields. A first conclusion to be drawn from these short-term estimation results is that participation in developmental screening causes subsequent medical treatment of preschoolers at the paediatrician and ophthalmologist. ${ }^{19}$ The insignificant (negative) effect on GPs' subsequent medical services indicates that doctors in this group do not conduct their own additional treatment. If at all, follow-up costs borne by this group of doctors arise exclusively from subsequent referrals to paediatricians and ophthalmologists.

The remainder of the table summarizes the results for preschoolers with low and higher SES separately. This comparison reveals that the effects of screening on interventions are driven mainly by low SES preschoolers. Expenditure for outpatient medical care increases by as much as $€ 405.5$ (+133 percent) in this group. The disaggregated analysis reveals significant effects for paediatricians $(€ 239.2)$ and ear-nose-and-throat (ENT) specialists (€37.5). A weakly statistically significant effect is observed for radiologists. We conclude that screening doctors diagnose developmental disorders in low SES preschoolers, which leads to substantial further medical treatment. In addition, there is a weakly statistically significant effect on hospitalization; however, we find no significant effect on the consumption of medical drugs.

By comparison, the only significant increase in follow-up expenditure for high SES preschoolers is for ophthalmologists. Participation in developmental screening triggers additional expenditure for ophthalmologists in the amount of $€ 25$. Furthermore, participation in developmental screening is estimated to reduce expenditure for medical drugs by $€$ 71.4. A potential explanation is that families with higher SES may reduce or even

\footnotetext{
${ }^{19}$ The ITT estimates are qualitatively identical to the LATE results. However, the coefficients are substantially lower due to imperfect compliance.
} 
stop unnecessary medication for their children as a consequence of doctor's consultation during the screening exam. ${ }^{20}$

\subsection{Effect of Participation on Long-run Healthcare Costs}

Our estimation results of the effect of developmental screening on long-run healthcare costs are summarized in Table 5. The different expenditure categories are the sum over the period when children are between 6 and 10.5 years of age. Column (3) shows that on average, developmental screening participation has no impact on long-term healthcare costs for the full sample. This holds true for the inpatient and outpatient sector. As a result, it can be concluded that the increase in follow-up expenditure for services provided by paediatricians and ophthalmologists cannot be compensated by a reduction in longterm diagnostic and/or therapeutic services. The separate analysis for preschoolers from low and higher SES preschoolers broadly supports this conclusion based on the full sample.

The case of high SES preschoolers is quite clear. Given that we find little evidence for subsequent medical interventions, with the exception of expenditure for ophthalmologists, we cannot expect substantial cost savings in the long run. This expectation is consistently supported by our regression results summarized in column (7). The effects on expenditure in the outpatient sector (in the aggregate and, to a lesser extent, for the different medical specialists) are estimated quite precisely and suggest a zero effect. While the effects on medication and hospitalization are estimated less precisely, they do not indicate cost savings in the long run either.

The case of low SES preschoolers is harder to assess. First, since we observe significant interventions, there is at least a potential for future cost savings. Indeed, with few exceptions, we observe negative point estimates in column (5), albeit with large standard errors. The only marginally significant effect is a reduction in the expenditure for GPs. Participation is estimated to reduce long-run expenditure for GP treatment by $€ 173.5$, or about 83 percent. Both alternative specifications confirm these long-run results and suggest for low SES preschoolers at the 10 percent level a significantly negative effect of screening participation on GP expenditure in the long run, whereas the effects on all other outcomes remain statistically insignificant. ${ }^{21}$ While it is clear that these savings in the long run cannot compensate for the increase in expenditure due to the intervention in the short run, the result provides at least some evidence for cost saving effects of the screening programme in low SES preschoolers.

\footnotetext{
${ }^{20}$ In the Web Appendix, we summarize estimation results for the models using the two alternative specifications of the treatment variable. See Table A.1 for the specification using participation in two or more screenings $\left(S_{i}^{2,3}\right)$ and Table A.2 for the specification using the absolute number of screenings $\left(S_{i}^{a b s}\right)$. Both alternative specifications provide qualitatively identical and quantitatively very comparable results.

${ }^{21}$ Detailed estimation output summarized in the Web Appendix shows that participation in two or more screenings (see Table A.3) reduces long-term GP expenditure by $€ 126.5$, and one additional screening reduces the same expenditure category by $€ 49.1$. In both alternative specifications, the t-statistic is marginally high compared to the baseline scenario.
} 


\section{Discussion}

For high SES preschoolers, we find a consistent picture with little evidence for interventions and consistently no effect on healthcare costs in the long run. There are two equally plausible explanations for this finding, with the same broad conclusion. First, very few high SES preschoolers have developmental disorders that would require an intervention. Alternatively, developmental disorders among high SES preschoolers are also identified in the counter-factual situation without screening participation. In this case, observant parents identify disorders themselves and consult medical specialists proactively. Furthermore, it may occur that these parents regularly consult a paediatrician irrespective of any screening programme, and the doctor identifies a developmental disorder during these consultations. In either case, we conclude that the developmental screenings are not cost-effective for this group.

The results for low SES preschoolers are harder to assess. We find clear evidence for interventions, but only weak evidence for cost savings in the long run. We see two competing interpretations for this estimation result. First, screening doctors identify developmental disorders in a significant share of low SES preschoolers. However, the subsequent intervention does not dampen future healthcare costs. Nevertheless, the treated preschoolers may still benefit from the intervention. An alternative explanation refers to supply-induced or at least supply-determined follow-up healthcare services. In other words, screening doctors do not identify developmental disorders, but recommend additional diagnostic and therapeutic services to raise their income. The fact that the increase in follow-up treatment almost exclusively occurs in low SES preschoolers might indicate that the lower is the parents' level of health literacy, the more successful are physicians' efforts to sell additional unnecessary healthcare services. To distinguish between these two explanations, we provide a further empirical analysis.

Supply inducement Follow-up treatments are provided by either the screening doctor him- or herself or another resident doctor. In the latter case, we can distinguish between cases in which parents consulted the non-screening doctor, first, owing to a referral by the screening (or any other) doctor, and second, due to their own initiative. This distinction is useful, since a referring doctor does not receive financial reward for his or her referral. ${ }^{22}$ Thus, 'referred' interventions cannot represent any form of supply inducement and it seems safe to assume that the medical indication is the main reason for referring a preschooler. In other words, if we find an effect of screening participation on follow-up expenditure borne by referrals, we can unequivocally interpret this as true interventions. ${ }^{23}$

Following this logic, we reperform our regression analysis on the effects of participa-

\footnotetext{
${ }^{22}$ We abstract here from network effects between the referring and receiving doctors.

${ }^{23}$ By contrast, from a zero effect, we cannot conclude that increases in follow-up expenditure are due to supply inducement.
} 
tion on the scope of intervention (from Table 4) based on a new dependent variable that captures only follow-up expenditure due to 'referred' interventions. The new results are summarized in Table 6. A comparison of the respective means in the first column of these two tables shows which proportion of total spending on the respective medical specialists is triggered by referrals from other doctors. ${ }^{24}$

The estimation coefficients in Table 6 indicate that participation has a significant $(t-$ statistics are about 1.7) and positive impact on 'referred interventions' to ENT specialists and radiologists. As before, these effects are driven mainly by the group of low SES preschoolers. For this group, participation leads to a fourfold and fivefold increase in medically justified expenditure for ENT and radiological services, respectively. This is in support of our interpretation that screening doctors identify developmental disorders in low SES preschoolers and provide/initiate an intervention. ${ }^{25}$

\section{Conclusions}

We evaluated the cost-effectiveness of a nationwide physician-based developmental screening programme for preschoolers comprising examinations at the ages of 24,36 , and 48 months. Identification was based on a fuzzy regression discontinuity design that exploited a sharp birthday cutoff-based discontinuity in the eligibility for a financial incentive for programme participation. Families with low and higher SES responded equally to this incentive, and eligible children were 14 percentage points more likely to be screened.

For high SES preschoolers we found a consistent picture with little evidence for interventions and consistently no effect on healthcare costs in the long run. Thus, high SES preschoolers have either little to no developmental disorders, or they also receive a treatment in the counter-factual situation without screening participation. For low SES preschoolers, we found clear evidence for interventions, but only weak evidence for cost savings in the long run. Thus, low SES preschoolers have identifiable developmental disorders. However, long-run cost savings in the healthcare system cannot compensate for the expenditure for the interventions.

We conclude that this physician-based developmental screening programme for preschoolers is in general not cost-effective in the observed time horizon, as it is unable to reduce long-term healthcare costs significantly. This holds particularly true for preschoolers with high SES. For this group, which comprises about 75 percent of the total preschooler pop-

\footnotetext{
${ }^{24}$ In the case of the paediatrician, this proportion is very low $(4.8 / 100.3=0.05)$, while for ophthalmologists (0.29) and ENT specialists (0.43), it is substantial, and for laboratories (0.93) and radiologists (0.94), it comprises the vast majority.

${ }^{25}$ The coefficients for paediatricians are economically and statistically insignificant. This suggests that GPs do not refer screened children to paediatricians for further interventions. The comparison with the highly significant effect for paediatricians in Table 4 (see column 5) indicates that screening paediatricians create their own revenues. In the absence of information on preschoolers' health status, we cannot evaluate whether these revenues are owing to justified interventions or are supply-induced.
} 
ulation, we consider the programme to be clearly ineffective, since it does not even lead to substantial interventions. The case of low SES preschoolers, who comprise about 25 percent of the total preschooler population, is less clear. We cannot conclude that the programme is ineffective for this group. Since we find substantial interventions, the treatment may generate benefits for children without leaving any trace in long-term healthcare expenditure. Unlike screening programmes for adults, which focus on early detection and treatment of life-threatening and expensive diseases, developmental screening examinations for children focus on identifying and reducing developmental deficits at an early stage of childhood. An early intervention with respect to these deficits can be expected to improve also the conditions for their human capital development, and may not necessarily dampen future healthcare costs.

Our results suggest that a promising way to improve the accuracy and effectiveness of developmental screenings for preschoolers would be to focus-at least in comparable institutional settings - on subjects with a higher likelihood of otherwise untreated developmental disorders, such as low SES preschoolers. These programmes should be accompanied by comprehensive evaluation, which includes direct health outcomes and other important developmental indicators focusing on human capital and social skills. ${ }^{26}$ To continue or implement these programmes, and to justify their substantial costs, evidence is needed that shows beneficial effects on other outcome dimensions beyond healthcare spending. Ideally, such evaluations would show that the programme-while not reducing healthcare costs - may help to improve the starting conditions of underprivileged children as a prerequisite for healthy and professionally successful lives.

Finally, measures and guidelines that help to rule out supply-induced follow-up treatment are desirable. In particular, less educated parents with probable low health literacy may be more affected directly by supply-induced demand for paediatricians. Managed care techniques, including binding treatment pathways and reviewing processes for the medical necessity of specific services, could help to limit the amount of supply-determined healthcare services and to improve the quality of care.

\footnotetext{
${ }^{26}$ For Austria, at the moment, these additional outcome dimensions cannot be analysed owing to data restrictions.
} 


\section{References}

Almond, Douglas and Janet Currie (2011), Human Capital Development before Age Five, in O.Ashenfelter and D.Card, eds, 'Handbook of Labor Economics', Vol. 4b, Elsevier, pp. $1315-1486$.

American Academy of Pediatrics (2010), 'Reaffirmation of Policy Statement: Identifying Infants and Young Children With Developmental Disorders in the Medical Home: An Algorithm for Developmental Surveillance and Screening', Pediatrics 125(2), e444e445.

Avellar, Sarah A. and Lauren H. Supplee (2013), 'Effectiveness of Home Visiting in Improving Child Health and Reducing Child Maltreatment', Pediatrics 132(Supplement 2), S90-S99.

Barker, David J. (1995), 'Fetal Origins of Coronary Heart Disease', British Medical Journal 311, 171-174.

Boyle, Coleen A., Sheree Boulet, Laura A. Schieve, Robin A. Cohen, Stephen J. Blumberg, Marshalyn Yeargin-Allsopp, Susanna Visser and Michael D. Kogan (2011), 'Trends in the Prevalence of Developmental Disabilities in US Children, 1997-2008', Pediatrics 127(6), 1034-1042.

Buckles, Kasey S. and Daniel M. Hungerman (2013), 'Season of Birth and Later Outcomes: Old Questions, New Answers', Review of Economics and Statistics 95(3), 711-724.

Cadman, David, Larry W. Chambers, Stephen D. Walter, Ruth Ferguson, Nancy Johnston and Jane McNamee (1987), 'Evaluation of Public Health Preschool Child Developmental Screening: The Process and Outcomes of a Community Program', American Journal of Public Health 77(1), 45-51.

Campbell, Frances A. and Craig T. Ramey (1994), 'Effects of Early Intervention on Intellectual and Academic Achievement: a Follow-Up Study of Children from Low-Income Families', Child Development 65(2), 684-698.

Campbell, Frances, Gabriella Conti, James J. Heckman, Seong Hyeok Moon, Rodrigo Pinto, Elizabeth Pungello and Yi Pan (2014), 'Early Childhood Investments Substantially Boost Adult Health', Science 343(6178), 1478-1485.

Carneiro, Pedro and Rita Ginja (2014), 'Long Term Impacts of Compensatory Preschool on Health and Behavior: Evidence from Head Start', American Economic Journal: Economic Policy 6(4), 1-42.

Chakrabarti, Suniti and Eric Fombonne (2001), 'Pervasive Developmental Disorders in Preschool Children', Journal of the American Medical Association 285(24), 3093-3099.

Chou, Roger, Tracy Dana and Christina Bougatsos (2011), 'Screening for Visual Impairment in Children Ages 1-5 Years: Update for the USPSTF', Pediatrics 127(2), 20100264 .

Conti, Gabriella and James J. Heckman (2013), 'The Developmental Approach to Child and Adult Health', Pediatrics 131(Supplement 2), S133-S141. 
Council on Children With Disabilities, Section on Developmental Behavioral Pediatrics, Bright Futures Steering Committee and Medical Home Initiatives for Children With Special Needs Project Advisory Committee (2006), 'Identifying Infants and Young Children With Developmental Disorders in the Medical Home: An Algorithm for Developmental Surveillance and Screening', Pediatrics 118(1), 405-420.

Cunha, Flavio and James Heckman (2007), 'The Technology of Skill Formation', American Economic Review 97(2), 31-47.

Currie, Jante and Maya Rossin-Slater (2015), 'Early-life Origins of Lifecycle Wellbeing: Research and Policy Implications', Journal of Policy Analysis and Management 34(1), 208-242.

Duncan, Greg J. and Katherine Magnuson (2013), 'Investing in Preschool Programs', Journal of Economic Perspectives 27(2), 109-132.

Gönenc, R., Maria M. Hofmarcher and Andreas Wörgötter (2011), Reforming Austria's Highly Regarded but Costly Health System, OECD Economics Department Working Papers 895, OECD, France.

McCrary, Justin (2008), 'Manipulation of the Running Variable in the Regression Discontinuity Design: A Density Test', Journal of Econometrics 142(2), 698-714.

Moyer, Virginia A. and Margaret Butler (2004), 'Gaps in the Evidence for Well-Child Care: A Challenge to Our Profession', Pediatrics 114(6), 1511-1521.

Peacock, Shelley, Stephanie Konrad, Erin Watson, Darren Nickel and Nazeem Muhajarine (2013), 'Effectiveness of Home Visiting Programs on Child Outcomes: A Systematic Review', BMC Public Health 13(1), 17-30.

Staiger, Douglas and James H. Stock (1997), 'Instrumental Variables Regression with Weak Instruments', Econometrica 65(3), 557-586.

Sweet, Monica A. and Mark I. Appelbaum (2004), 'Is Home Visiting an Effective Strategy? A Meta-Analytic Review of Home Visiting Programs for Families with Young Children', Child Development 75(5), 1435-1456.

Williams, Cathy, Kate Northstone, Richard A. Harrad, John M. Sparrow and Ian Harvey (2002), 'Amblyopia Treatment Outcomes After Screening Before or At Age 3 Years: Follow Up from Randomised Trial', British Medical Journal 324(7353), 1549-1551. 


\section{Tables and Figures}

Figure 1: Participation Rate in Developmental Screenings per Day of Birth

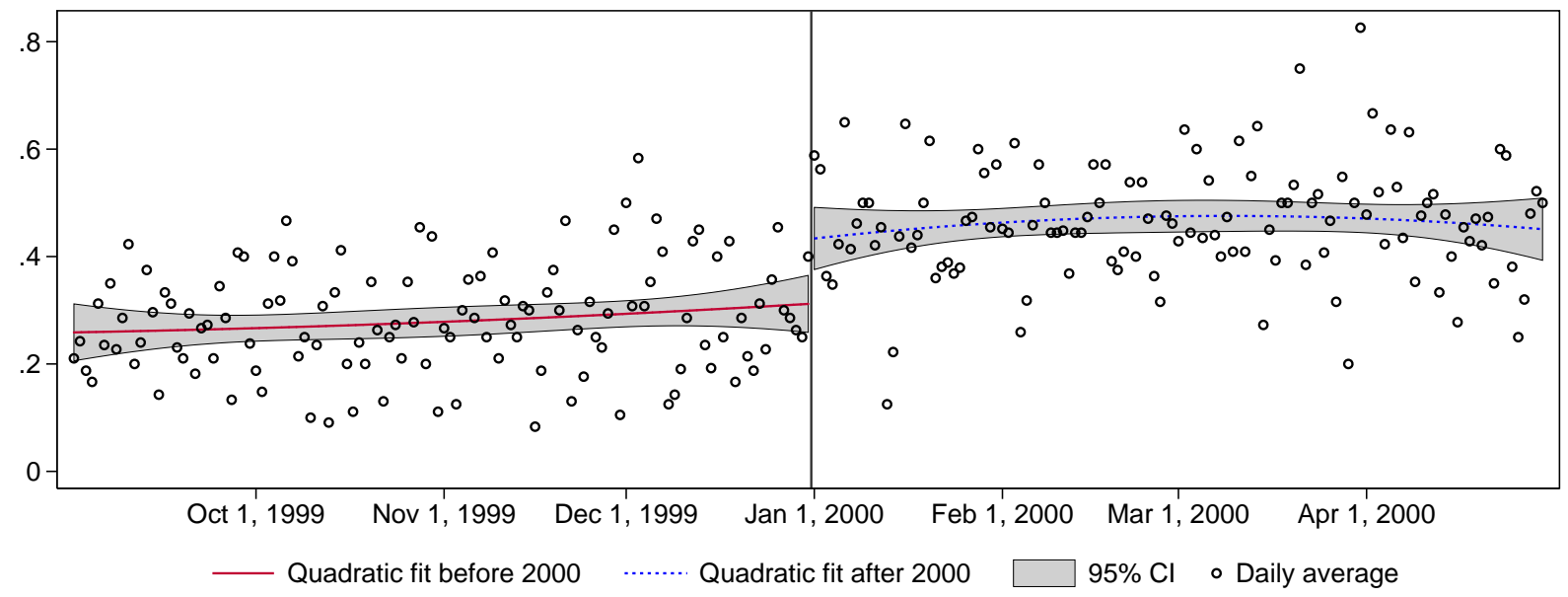

Figure 2: Number of Births per Day

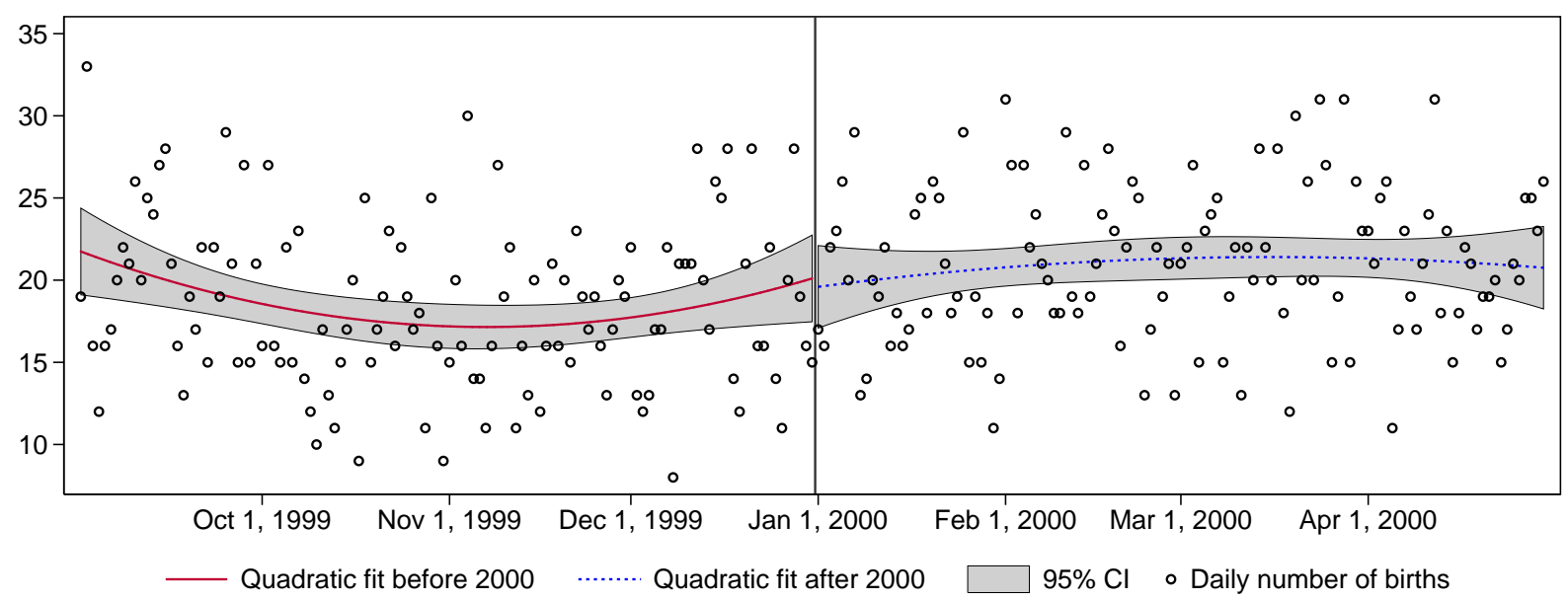




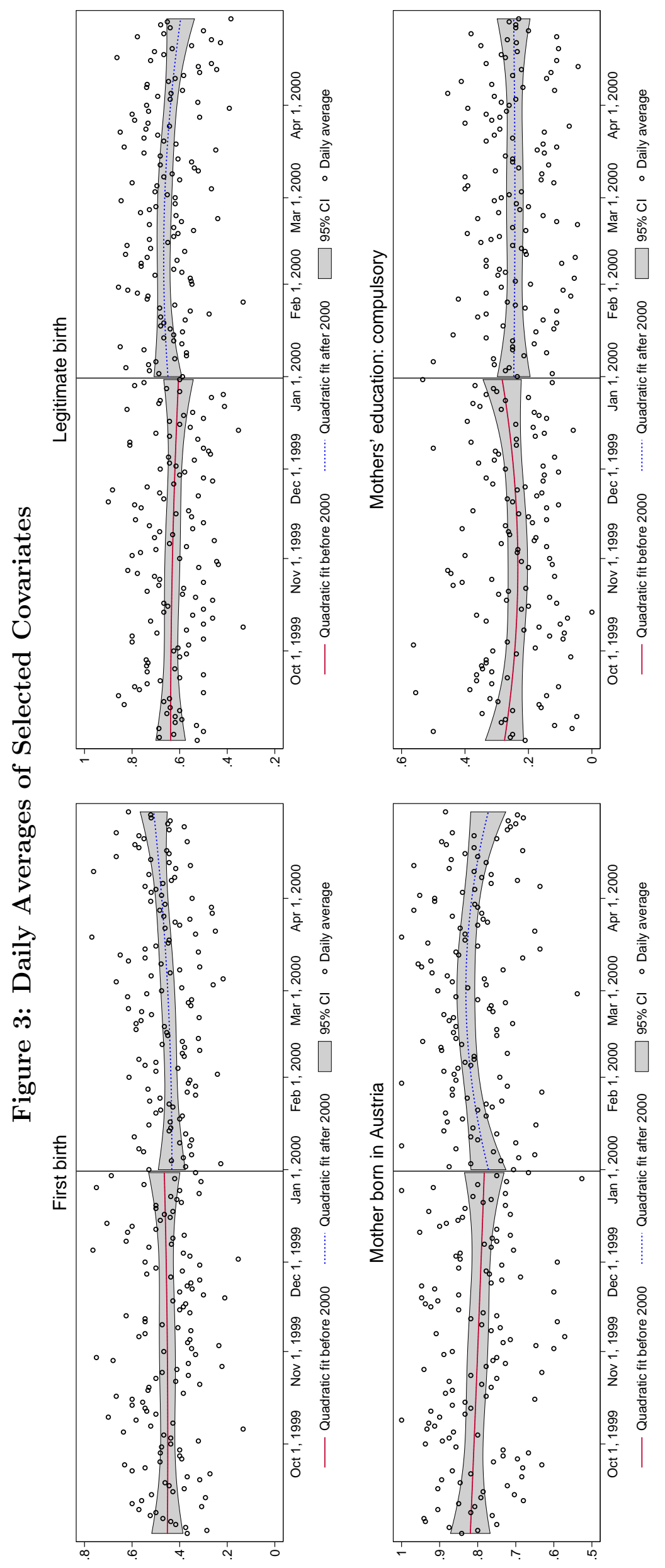


Table 1: Overview of the Mother-Child-Pass Examination Programme

\begin{tabular}{|c|c|c|c|c|}
\hline No. & AGE & EXAMINATIONS & FINANCIAL & INCENTIVE \\
\hline & & & Nationwide & $\begin{array}{l}\text { Upper } \\
\text { Austria }^{c}\end{array}$ \\
\hline Pren & atal screening exami & nations & & \\
\hline 1 & Until $16^{t h}$ week & $\begin{array}{l}\text { Obstetric examination; laboratory } \\
\text { tests }\end{array}$ & yes & yes \\
\hline & $8^{\text {th }}$ to $12^{\text {th }}$ week & Ultrasound $^{a}$ & & \\
\hline 2 & $17^{t h}$ to $20^{t h}$ week & $\begin{array}{l}\text { Obstetric examination; internal } \\
\text { examination }\end{array}$ & yes & yes \\
\hline & $18^{\text {th }}$ to $22^{\text {nd }}$ week & Ultrasound $^{a}$ & & \\
\hline 3 & $25^{t h}$ to $28^{t h}$ week & $\begin{array}{l}\text { Obstetric examination; laboratory } \\
\text { tests }\end{array}$ & yes & yes \\
\hline 4 & $\begin{array}{l}30^{\text {th }} \text { to } 34^{\text {th }} \text { week } \\
30^{\text {th }} \text { to } 34^{\text {th }} \text { week }\end{array}$ & $\begin{array}{l}\text { Obstetric examination } \\
\text { Ultrasound }^{a}\end{array}$ & yes & yes \\
\hline 5 & $34^{\text {th }}$ to $38^{\text {th }}$ week & Obstetric examination & yes & yes \\
\hline Post & natal screening exam & inations of infants (up to 14 months, & & \\
\hline 1 & $1^{\text {st }}$ week & $\begin{array}{l}\text { Child examination; hip } \\
\text { ultrasound }^{b}\end{array}$ & yes & yes \\
\hline 2 & $4^{\text {th }}$ to $7^{\text {th }}$ week & $\begin{array}{l}\text { Child examination; orthopaedic } \\
\text { examination }\end{array}$ & yes & yes \\
\hline & $6^{\text {th }}$ to $8^{\text {th }}$ week & Hip ultrasound ${ }^{b}$ & & \\
\hline 3 & $3^{\text {rd }}$ to $5^{\text {th }}$ month & Child examination & yes & yes \\
\hline 4 & $7^{\text {th }}$ to $9^{\text {th }}$ month & $\begin{array}{l}\text { Child examination; ear, nose, and } \\
\text { throat examination }\end{array}$ & yes & yes \\
\hline 5 & $10^{t h}$ to $14^{t h}$ month & $\begin{array}{l}\text { Child examination; eye } \\
\text { examination }\end{array}$ & yes & yes \\
\hline Deve & lopmental screening & examinations of toddlers and prescho & lers (from 2 & o 4 years) \\
\hline D1 & $22^{\text {nd }}$ to $26^{\text {th }}$ month & Anamnesis; physical examination; & no & yes \\
\hline D2 & $34^{\text {th }}$ to $38^{\text {th }}$ month & $\begin{array}{l}\text { nutritional status; behaviour; } \\
\text { mental development; speech and }\end{array}$ & no & yes \\
\hline D3 & $46^{\text {th }}$ to $50^{\text {th }}$ month & $\begin{array}{l}\text { language; comprehensive eye and } \\
\text { vision examination at D1 }\end{array}$ & no & yes \\
\hline
\end{tabular}

Notes: ${ }^{a}$ Ultrasound exams are recommended but not required for receipt of financial incentive.

${ }^{b}$ The hip ultrasound examination is recommended but not required for receipt of financial incentive.

${ }^{c}$ Only children born on 1 January 2000 or later are eligible for the financial incentive. 
Table 2: Effect of Financial Incentives on Participation

\begin{tabular}{|c|c|c|c|c|c|c|}
\hline \multirow[b]{2}{*}{ Dependent Variable: } & \multicolumn{3}{|c|}{$\begin{array}{l}\text { LINEAR TRENDS } \\
\text { See eq. }(1)\end{array}$} & \multicolumn{3}{|c|}{$\begin{array}{c}\text { MONTH FIXED EFFECTS } \\
\text { See eq. }(3)\end{array}$} \\
\hline & $\begin{array}{l}S_{i}^{3} \\
(1)\end{array}$ & $\begin{array}{c}S_{i}^{2,3} \\
(2)\end{array}$ & $\begin{array}{c}S_{i}^{a b s} \\
(3)\end{array}$ & $\begin{array}{l}S_{i}^{3} \\
(4)\end{array}$ & $\begin{array}{c}S_{i}^{2,3} \\
(5)\end{array}$ & $\begin{array}{c}S_{i}^{a b s} \\
(6)\end{array}$ \\
\hline$T_{i}$ & $\begin{array}{l}0.147^{* * *} \\
(0.027)\end{array}$ & $\begin{array}{l}0.164^{* * *} \\
(0.028)\end{array}$ & $\begin{array}{l}0.384^{* * *} \\
(0.067)\end{array}$ & $\begin{array}{l}0.145^{* * *} \\
(0.018)\end{array}$ & $\begin{array}{l}0.140^{* * *} \\
(0.020)\end{array}$ & $\begin{array}{l}0.359^{* * *} \\
(0.047)\end{array}$ \\
\hline$B_{i}-c$ & $\begin{array}{c}0.000 \\
(0.000)\end{array}$ & $\begin{array}{c}0.000 \\
(0.000)\end{array}$ & $\begin{array}{c}0.000 \\
(0.001)\end{array}$ & & & \\
\hline$\left(B_{i}-c\right) \times T_{i}$ & $\begin{array}{c}0.000 \\
(0.000)\end{array}$ & $\begin{array}{c}0.000 \\
(0.000)\end{array}$ & $\begin{array}{c}0.000 \\
(0.001)\end{array}$ & & & \\
\hline$P_{i}$ & & & & $\begin{array}{l}0.051^{* * *} \\
(0.013)\end{array}$ & $\begin{array}{l}0.052^{* * *} \\
(0.014)\end{array}$ & $\begin{array}{l}0.164^{* * *} \\
(0.033)\end{array}$ \\
\hline$M_{i, j}$ & No & No & No & Yes & Yes & Yes \\
\hline \multicolumn{7}{|l|}{ Further Covariates: } \\
\hline First birth & $\begin{array}{l}0.160^{* * *} \\
(0.016)\end{array}$ & $\begin{array}{l}0.195^{* * *} \\
(0.016)\end{array}$ & $\begin{array}{l}0.519^{* * *} \\
(0.037)\end{array}$ & $\begin{array}{l}0.171^{* * *} \\
(0.011)\end{array}$ & $\begin{array}{l}0.212^{* * *} \\
(0.011)\end{array}$ & $\begin{array}{l}0.571^{* * *} \\
(0.027)\end{array}$ \\
\hline Preterm birth & $\begin{array}{c}0.024 \\
(0.039)\end{array}$ & $\begin{array}{r}0.076^{*} \\
(0.039)\end{array}$ & $\begin{array}{c}0.128 \\
(0.096)\end{array}$ & $\begin{array}{c}0.006 \\
(0.026)\end{array}$ & $\begin{array}{c}0.038 \\
(0.027)\end{array}$ & $\begin{array}{c}0.049 \\
(0.066)\end{array}$ \\
\hline Low birth weight & $\begin{array}{c}0.002 \\
(0.037)\end{array}$ & $\begin{array}{c}0.016 \\
(0.036)\end{array}$ & $\begin{array}{c}0.030 \\
(0.089)\end{array}$ & $\begin{array}{c}0.013 \\
(0.025)\end{array}$ & $\begin{array}{c}0.006 \\
(0.026)\end{array}$ & $\begin{array}{c}0.010 \\
(0.064)\end{array}$ \\
\hline Mother's age & $\begin{array}{c}0.001 \\
(0.001)\end{array}$ & $\begin{array}{c}0.002 \\
(0.002)\end{array}$ & $\begin{array}{c}0.005 \\
(0.004)\end{array}$ & $\begin{array}{c}0.002^{* *} \\
(0.001)\end{array}$ & $\begin{array}{l}0.003^{* *} \\
(0.001)\end{array}$ & $\begin{array}{l}0.005^{* *} \\
(0.003)\end{array}$ \\
\hline Legitimate birth & $\begin{array}{c}0.033^{* *} \\
(0.016)\end{array}$ & $\begin{array}{c}0.035^{* *} \\
(0.016)\end{array}$ & $\begin{array}{c}0.067^{*} \\
(0.038)\end{array}$ & $\begin{array}{l}0.029^{* * *} \\
(0.011)\end{array}$ & $\begin{array}{l}0.024^{* *} \\
(0.011)\end{array}$ & $\begin{array}{c}0.049^{*} \\
(0.027)\end{array}$ \\
\hline Mother born in Austria & $\begin{array}{l}0.088^{* * *} \\
(0.018)\end{array}$ & $\begin{array}{l}0.064^{* * *} \\
(0.020)\end{array}$ & $\begin{array}{l}0.207^{* * *} \\
(0.047)\end{array}$ & $\begin{array}{l}0.063^{* * *} \\
(0.012)\end{array}$ & $\begin{array}{l}0.052^{* * *} \\
(0.014)\end{array}$ & $\begin{array}{l}0.164^{* * *} \\
(0.033)\end{array}$ \\
\hline \multicolumn{7}{|c|}{ Mother's educational attainment (base group: compulsory school) } \\
\hline Vocational /lower sec. & $\begin{array}{l}0.049^{* * *} \\
(0.017)\end{array}$ & $\begin{array}{l}0.074^{* * *} \\
(0.018)\end{array}$ & $\begin{array}{l}0.179^{* * *} \\
(0.044)\end{array}$ & $\begin{array}{l}0.048^{* * *} \\
(0.011)\end{array}$ & $\begin{array}{l}0.055^{* * *} \\
(0.013)\end{array}$ & $\begin{array}{l}0.151^{* * *} \\
(0.030)\end{array}$ \\
\hline Upper sec./tertiary & $\begin{array}{c}0.053^{* *} \\
(0.022)\end{array}$ & $\begin{array}{l}0.081^{\text {*** }} \\
(0.023)\end{array}$ & $\begin{array}{l}0.188^{* * *} \\
(0.055)\end{array}$ & $\begin{array}{l}0.054^{* * *} \\
(0.015)\end{array}$ & $\begin{array}{l}0.072^{* * *} \\
(0.016)\end{array}$ & $\begin{array}{l}0.177^{* * *} \\
(0.039)\end{array}$ \\
\hline Constant & $\begin{array}{c}0.077 \\
(0.048)\end{array}$ & $\begin{array}{l}0.185^{\text {*** }} \\
(0.051)\end{array}$ & $\begin{array}{l}0.775^{* * *} \\
(0.122)\end{array}$ & $\begin{array}{c}0.013 \\
(0.033)\end{array}$ & $\begin{array}{l}0.161^{* * *} \\
(0.037)\end{array}$ & $\begin{array}{l}0.656^{* * *} \\
(0.087)\end{array}$ \\
\hline Preschoolers are born & \multicolumn{3}{|c|}{$09 / 1999-04 / 2000$} & \multicolumn{3}{|c|}{ 09/98 - 04/99 \& 09/99 - 04/00 } \\
\hline Number of observations & 4,788 & 4,788 & 4,788 & 9,516 & 9,516 & 9,516 \\
\hline Mean of dependent variable & 0.378 & 0.563 & 1.700 & 0.313 & 0.499 & 1.519 \\
\hline$F$ statistic on $T_{i}$ & 29.6 & 35.0 & 33.2 & 63.0 & 50.0 & 58.0 \\
\hline
\end{tabular}

Notes: This table summarizes estimation results on the effect of the eligibility for the financial incentive on developmental screening participation based on alternative specifications. The first three columns are based on the model described by eq. (1), which uses the sample of all children born between September 1999 and April 2000. The remaining three columns are based on the model described by eq. (3), which uses the sample of all children born between September 1998 and April 1999 and September 1999 and April 2000. In the first and fourth columns, the dependent variable is a binary indicator equal to one if child $i$ has participated in all three developmental screening examinations, and zero otherwise. In the second and fifth columns, the dependent variable is a binary indicator equal to one if child $i$ has participated in at least two developmental screening examinations, and zero otherwise. In the third and sixth columns, the dependent variable captures the absolute number of developmental screening examinations in which child $i$ participated. The method of estimation is least squares and robust standard errors are reported in parentheses, * $p<0.1,{ }^{* *} p<0.05$, and ${ }^{* * *} p<0.01$. 
Table 3: Heterogeneity in Effect of Financial Incentives on Participation

\begin{tabular}{lccccc}
\hline \multicolumn{1}{c}{$(1)$} & $(2)$ & $(3)$ & $(4)$ & $(5)$ \\
& $\mathrm{N}$ & Mean & Estimate & S.E. & F-stat. \\
\hline FULL SAMPLE & 9,516 & 0.313 & $0.145^{* * *}$ & $(0.018)$ & 63.0 \\
SOCIO-ECONOMIC STATUS & & & & & \\
Low SES & 2,346 & 0.242 & $0.146^{* * *}$ & $(0.034)$ & 18.3 \\
Higher SES & 7,170 & 0.336 & $0.143^{* * *}$ & $(0.022)$ & 44.0 \\
MoTHER'S COUNTRY OF BIRTH & & & & \\
Foreign country & 1,810 & 0.238 & $0.071^{*}$ & $(0.039)$ & 3.4 \\
Austria & 7,706 & 0.330 & $0.162^{* * *}$ & $(0.021)$ & 61.7 \\
LEGITIMACY OF BIRTH & & & & & \\
Out of wedlock & 3,334 & 0.339 & $0.136^{* * *}$ & $(0.032)$ & 18.2 \\
Legitimate & 6,182 & 0.298 & $0.149^{* * *}$ & $(0.022)$ & 45.1 \\
PARITY & & & & & \\
First birth & 4,252 & 0.404 & $0.131^{* * *}$ & $(0.029)$ & 19.8 \\
Higher order birth & 5,264 & 0.239 & $0.156^{* * *}$ & $(0.023)$ & 46.9 \\
\hline
\end{tabular}

Notes: This table summarizes estimation results on the effect of the eligibility for the financial incentive on developmental screening participation for different sample splits. The estimations are equivalent to those presented in column (4) of Table 2 (i.e. the dependent variable is a binary indicator equal to one if child $i$ has participated in all three developmental screening examinations, and zero otherwise; and the estimations follow the model described by eq. (3)). The method of estimation is least squares. Column (1) reports the number of observations, column (2) reports the mean of the dependent variable, column (3) reports the estimated coefficient, column (4) reports robust standard errors $\left({ }^{*} p<0.1,{ }^{* *} p<0.05\right.$, and $\left.{ }^{* * *} p<0.01\right)$, and column (5) reports the $F$ statistic on $T_{i}$ (test for a weak instrument). ${ }^{a}$ The preschooler's socio-economic status (SES) is defined according to his or her mother's educational attainment at birth. If the mother's highest degree is compulsory schooling, then the preschooler is defined as low SES. 
Table 4: Effect of Participation on Scope of Intervention

\begin{tabular}{|c|c|c|c|c|c|c|c|}
\hline & \multicolumn{3}{|c|}{$\begin{array}{c}\text { FUll SAMPle } \\
\text { OF PRESCHOOLERS }\end{array}$} & \multicolumn{2}{|c|}{$\begin{array}{c}\text { LOW SES } \\
\text { PRESCHOOLERS } \\
\end{array}$} & \multicolumn{2}{|c|}{$\begin{array}{c}\text { HiGH SES } \\
\text { PRESCHOOLERS } \\
\end{array}$} \\
\hline & $\begin{array}{c}(1) \\
\text { Mean }\end{array}$ & $\begin{array}{l}(2) \\
\text { ITT }\end{array}$ & $\begin{array}{c}(3) \\
\text { LATE }\end{array}$ & $\begin{array}{c}(4) \\
\text { Mean }\end{array}$ & $\begin{array}{c}(5) \\
\text { LATE }\end{array}$ & $\begin{array}{c}(6) \\
\text { Mean }\end{array}$ & $\begin{array}{c}(7) \\
\text { LATE }\end{array}$ \\
\hline \multicolumn{8}{|c|}{$\begin{array}{l}\text { AgGregate Health Spending Categories } \\
\text { Between } 18 \text { And } 54 \text { Months of Age }\end{array}$} \\
\hline Outpatient medical care (in euro) & 305.2 & $\begin{array}{c}11.0 \\
(10.3)\end{array}$ & $\begin{array}{c}75.7 \\
(68.5)\end{array}$ & 278.9 & $\begin{array}{c}405.5^{* * *} \\
(135.2)\end{array}$ & 313.7 & $\begin{array}{l}-42.8 \\
(86.6)\end{array}$ \\
\hline Medication (in euro) & 64.8 & $\begin{array}{l}-6.2 \\
(4.1)\end{array}$ & $\begin{array}{l}-42.8 \\
(29.3)\end{array}$ & 63.5 & $\begin{array}{c}25.2 \\
(56.0)\end{array}$ & 65.3 & $\begin{array}{c}-71.4^{* *} \\
(35.9)\end{array}$ \\
\hline Hospitalization (in days) & 1.9 & $\begin{array}{c}0.3 \\
(0.2)\end{array}$ & $\begin{array}{c}2.1 \\
(1.6)\end{array}$ & 2.6 & $\begin{array}{l}10.0^{*} \\
(5.6)\end{array}$ & 1.7 & $\begin{array}{l}-0.6 \\
(1.3)\end{array}$ \\
\hline \multicolumn{8}{|c|}{$\begin{array}{l}\text { Aggregated Spending on Medical Specialists } \\
\text { Between } 18 \text { And } 54 \text { Months of Age in Euro }\end{array}$} \\
\hline Paediatrician & 100.3 & $\begin{array}{c}11.6^{* *} \\
(5.5)\end{array}$ & $\begin{array}{l}79.9^{* *} \\
(34.7)\end{array}$ & 91.9 & $\begin{array}{c}239.2^{* * *} \\
(73.1)\end{array}$ & 103.0 & $\begin{array}{c}26.0 \\
(42.8)\end{array}$ \\
\hline General practitioner & 128.9 & $\begin{array}{l}-4.8 \\
(5.5)\end{array}$ & $\begin{array}{l}-33.3 \\
(38.6)\end{array}$ & 125.0 & $\begin{array}{c}57.5 \\
(73.6)\end{array}$ & 130.1 & $\begin{array}{l}-66.5 \\
(46.9)\end{array}$ \\
\hline Dentist & 11.8 & $\begin{array}{c}1.0 \\
(1.5)\end{array}$ & $\begin{array}{c}7.1 \\
(10.6)\end{array}$ & 9.9 & $\begin{array}{c}26.4 \\
(22.7)\end{array}$ & 12.4 & $\begin{array}{c}-0.1 \\
(12.0)\end{array}$ \\
\hline Ophthalmologist & 18.9 & $\begin{array}{l}3.0^{* *} \\
(1.3)\end{array}$ & $\begin{array}{c}20.7^{* *} \\
(8.8)\end{array}$ & 15.7 & $\begin{array}{c}4.4 \\
(16.7)\end{array}$ & 20.0 & $\begin{array}{l}25.0^{* *} \\
(10.6)\end{array}$ \\
\hline ENT specialist & 12.0 & $\begin{array}{c}1.1 \\
(1.6)\end{array}$ & $\begin{array}{c}7.3 \\
(11.1)\end{array}$ & 8.4 & $\begin{array}{l}37.5^{* *} \\
(18.2)\end{array}$ & 13.2 & $\begin{array}{c}-3.9 \\
(13.9)\end{array}$ \\
\hline Orthopaedist & 3.1 & $\begin{array}{c}0.9^{*} \\
(0.5)\end{array}$ & $\begin{array}{c}6.1 \\
(3.8)\end{array}$ & 2.3 & $\begin{array}{c}9.9 \\
(6.6)\end{array}$ & 3.4 & $\begin{array}{c}4.8 \\
(4.6)\end{array}$ \\
\hline Laboratory & 5.5 & $\begin{array}{c}-0.1 \\
(0.9)\end{array}$ & $\begin{array}{l}-0.4 \\
(6.0)\end{array}$ & 4.1 & $\begin{array}{c}3.8 \\
(9.5)\end{array}$ & 5.9 & $\begin{array}{l}-2.5 \\
(7.5)\end{array}$ \\
\hline Radiologist & 3.1 & $\begin{array}{c}0.4 \\
(0.6) \\
\end{array}$ & $\begin{array}{c}2.6 \\
(4.1) \\
\end{array}$ & 2.3 & $\begin{array}{l}12.9^{*} \\
(7.4)\end{array}$ & 3.3 & $\begin{array}{l}-1.1 \\
(5.0)\end{array}$ \\
\hline Number of observations & 9,516 & & & 2,346 & & 7,170 & \\
\hline $\begin{array}{l}\text { Notes: This table summarizes estimation resu } \\
\text { by different health spending categories aggrega } \\
\text { a separate regression, in which the dependent } \\
\text { aggregate health spending categories, and the } \\
\text { of estimation is two-stage least squares based } \\
\text { in Table } 2 \text {. Robust standard errors are repor } \\
\text { (3) provide the mean of the dependent variab } \\
\text { average treatment effect (LATE, based on the } \\
\text { dependent variable and the LATE for the samp } \\
\text { the mean of the dependent variable and the L }\end{array}$ & $\begin{array}{l}\text { the pane } \\
\text { the } \\
\text { in pare } \\
\text { the inte } \\
\text { ond sta } \\
\text { of low so } \\
\text { E for th }\end{array}$ & $\begin{array}{l}\text { umman } \\
\text { el dess } \\
\text { heses, } \\
\text { ion-to } \\
\text { for tl } \\
\text { o-econ } \\
\text { sample }\end{array}$ & 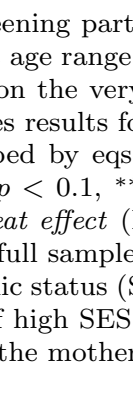 & $\begin{aligned}(3) \text { a } \\
p<0 \\
\text { TT, b }\end{aligned}$ & $\begin{array}{l}\text { and } 54 \mathrm{~m} \\
\text { upper par } \\
\text { on medica } \\
\text { (4), which } \\
\text { and }{ }^{* * *} \text { 1 } \\
\text { on the re } \\
\text { (4) and (5 } \\
\text { oolers. Co } \\
\text { rs. The pr }\end{array}$ & $\begin{array}{l}\text { inters } \\
\text { s. Ea } \\
\text { ummi } \\
\text { ecialis } \\
\text { udes } \\
\text {.01. } \\
\text { d for } \\
\text { ovide } \\
\text { as (6) }\end{array}$ & $\begin{array}{l}\text { I captured } \\
\text { try reflects } \\
\text { results for } \\
\text { 'he method } \\
\text { iates listed } \\
\text { mns (1) to } \\
\text { d the local } \\
\text { nean of the } \\
\text { (7) provide } \\
\text { is defined }\end{array}$ \\
\hline
\end{tabular}


Table 5: Effect of Participation on Long-run Healthcare Costs

\begin{tabular}{|c|c|c|c|c|c|c|c|}
\hline & \multicolumn{3}{|c|}{$\begin{array}{l}\text { Full SAMPle } \\
\text { OF Preschoolers }\end{array}$} & \multicolumn{2}{|c|}{$\begin{array}{c}\text { LOW SES } \\
\text { PRESCHOOLERS }\end{array}$} & \multicolumn{2}{|c|}{$\begin{array}{c}\text { High SES } \\
\text { PRESCHOOLERS }\end{array}$} \\
\hline & $\begin{array}{c}(1) \\
\text { Mean }\end{array}$ & $\begin{array}{l}(2) \\
\text { ITT }\end{array}$ & $\begin{array}{c}(3) \\
\text { LATE }\end{array}$ & $\begin{array}{c}(4) \\
\text { Mean }\end{array}$ & $\begin{array}{c}(5) \\
\text { LATE }\end{array}$ & $\begin{array}{c}(6) \\
\text { Mean }\end{array}$ & $\begin{array}{c}(7) \\
\text { LATE }\end{array}$ \\
\hline \multicolumn{8}{|c|}{$\begin{array}{l}\text { Aggregate Health Spending Categories } \\
\text { Between } 6 \text { And } 10.5 \text { Years of Age }\end{array}$} \\
\hline Outpatient medical care (in euro) & 969.3 & $\begin{array}{l}-23.0 \\
(41.3)\end{array}$ & $\begin{array}{l}-159.0 \\
(286.8)\end{array}$ & 915.5 & $\begin{array}{l}-585.8 \\
(571.6)\end{array}$ & 986.9 & $\begin{array}{l}-16.8 \\
(337.5)\end{array}$ \\
\hline Medication (in euro) & 151.4 & $\begin{array}{l}-13.4 \\
(14.1)\end{array}$ & $\begin{array}{l}-92.3 \\
(98.0)\end{array}$ & 147.5 & $\begin{array}{l}-130.8 \\
(168.6)\end{array}$ & 152.6 & $\begin{array}{c}-87.0 \\
(119.5)\end{array}$ \\
\hline Hospitalization (in days) & 2.2 & $\begin{array}{c}0.8 \\
(0.9)\end{array}$ & $\begin{array}{c}5.4 \\
(6.0)\end{array}$ & 3.6 & $\begin{array}{c}8.2 \\
(22.5)\end{array}$ & 1.8 & $\begin{array}{c}2.6 \\
(4.4)\end{array}$ \\
\hline \multicolumn{8}{|c|}{$\begin{array}{l}\text { AgGregated Spending on Medical Specialists } \\
\text { BETWEen } 6 \text { AND } 10.5 \text { Years of AgE in Euro }\end{array}$} \\
\hline Paediatrician & 69.4 & $\begin{array}{c}2.2 \\
(5.3)\end{array}$ & $\begin{array}{l}15.5 \\
(36.1)\end{array}$ & 74.2 & $\begin{array}{c}39.5 \\
(72.5)\end{array}$ & 67.8 & $\begin{array}{c}5.3 \\
(42.4)\end{array}$ \\
\hline General practitioner & 198.1 & $\begin{array}{c}-11.1^{*} \\
(6.6)\end{array}$ & $\begin{array}{l}-76.5 \\
(46.5)\end{array}$ & 208.3 & $\begin{array}{c}-173.5^{*} \\
(99.2)\end{array}$ & 194.7 & $\begin{array}{l}-45.8 \\
(53.7)\end{array}$ \\
\hline Dentist & 359.3 & $\begin{array}{c}0.6 \\
(22.9)\end{array}$ & $\begin{array}{c}4.3 \\
(158.2)\end{array}$ & 294.4 & $\begin{array}{c}-8.0 \\
(259.9)\end{array}$ & 380.5 & $\begin{array}{c}23.1 \\
(195.2)\end{array}$ \\
\hline Ophthalmologist & 43.7 & $\begin{array}{l}0.6 \\
(2.5)\end{array}$ & $\begin{array}{c}4.5 \\
(17.1)\end{array}$ & 38.9 & $\begin{array}{l}-12.2 \\
(34.6)\end{array}$ & 45.3 & $\begin{array}{c}9.6 \\
(20.1)\end{array}$ \\
\hline ENT specialist & 28.1 & $\begin{array}{c}0.1 \\
(2.8)\end{array}$ & $\begin{array}{c}1.0 \\
(19.3)\end{array}$ & 25.4 & $\begin{array}{c}5.8 \\
(39.0)\end{array}$ & 28.9 & $\begin{array}{c}-0.6 \\
(22.5)\end{array}$ \\
\hline Orthopaedist & 5.3 & $\begin{array}{c}0.1 \\
(0.8)\end{array}$ & $\begin{array}{c}0.7 \\
(5.2)\end{array}$ & 4.5 & $\begin{array}{l}-0.3 \\
(9.7)\end{array}$ & 5.5 & $\begin{array}{c}0.7 \\
(6.2)\end{array}$ \\
\hline Laboratory & 9.7 & $\begin{array}{c}1.5 \\
(1.2)\end{array}$ & $\begin{array}{l}10.3 \\
(8.0)\end{array}$ & 9.2 & $\begin{array}{c}-5.7 \\
(15.0)\end{array}$ & 9.8 & $\begin{array}{l}14.8 \\
(9.7)\end{array}$ \\
\hline Radiologist & 9.0 & $\begin{array}{l}-1.1 \\
(1.1)\end{array}$ & $\begin{array}{l}-7.5 \\
(7.9)\end{array}$ & 9.1 & $\begin{array}{l}-8.6 \\
(16.7)\end{array}$ & 9.0 & $\begin{array}{l}-7.3 \\
(9.1)\end{array}$ \\
\hline Number of observations & 9,516 & & & 2,346 & & 7,170 & \\
\hline \multicolumn{8}{|c|}{$\begin{array}{l}\text { Notes: This table summarizes estimation results of the effect of screening participation on long-run healthcare costs captured } \\
\text { by different health spending categories aggregated over the children's age range between } 6 \text { and } 10.5 \text { years. Each entry reflects } \\
\text { a separate regression, in which the dependent variable is indicated on the very left. The upper panel summarizes results for } \\
\text { aggregate health spending categories, and the lower panel summarizes results for spending on medical specialists. The method } \\
\text { of estimation is two-stage least squares based on the model described by eqs. (3) and (4), which includes covariates listed } \\
\text { in Table } 2 \text {. Robust standard errors are reported in parentheses, }{ }^{*} p<0.1,{ }^{* *} p<0.05, \text { and }{ }^{* * *} p<0.01 \text {. Columns (1) to } \\
\text { (3) provide the mean of the dependent variable, the intention-to-treat effect (ITT, based on the reduced form) and the local } \\
\text { average treatment effect (LATE, based on the second stage) for the full sample. Columns (4) and (5) provide the mean of the } \\
\text { dependent variable and the LATE for the sample of low socio-economic status (SES) preschoolers. Columns }(6) \text { and (7) provide } \\
\text { the mean of the dependent variable and the LATE for the sample of high SES preschoolers. The preschooler's SES is defined } \\
\text { according to his or her mother's educational attainment at birth. If the mother's highest degree is compulsory schooling, then } \\
\text { the preschooler is defined as low SES. }\end{array}$} \\
\hline
\end{tabular}


Table 6: Effect of Participation on Scope of Intervention: Expenditure borne by referrals

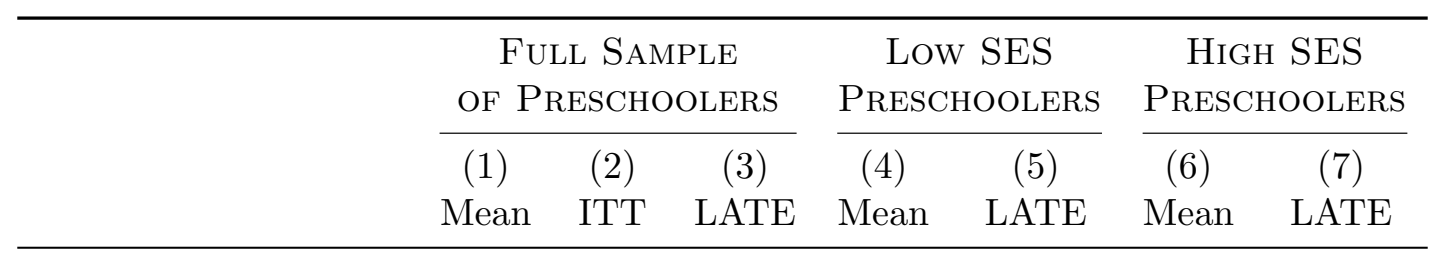

\begin{tabular}{|c|c|c|c|c|c|c|c|}
\hline \multicolumn{8}{|c|}{$\begin{array}{l}\text { AgGregated Spending on Medical SpeC } \\
\text { Between } 18 \text { And } 54 \text { Months of Age in E }\end{array}$} \\
\hline Paediatrician & 4.8 & $\begin{array}{c}-0.3 \\
(0.9)\end{array}$ & $\begin{array}{l}-2.1 \\
(6.2)\end{array}$ & 7.0 & $\begin{array}{c}7.2 \\
(16.9)\end{array}$ & 4.0 & $\begin{array}{l}-5.5 \\
(6.3)\end{array}$ \\
\hline General practitioner & 4.7 & $\begin{array}{l}-1.0 \\
(0.6)\end{array}$ & $\begin{array}{c}-6.7 \\
(4.3)\end{array}$ & 4.0 & $\begin{array}{c}0.4 \\
(7.0)\end{array}$ & 5.0 & $\begin{array}{c}-9.3^{*} \\
(5.3)\end{array}$ \\
\hline Dentist & 0.0 & $\begin{array}{c}-0.0 \\
(0.0)\end{array}$ & & 0.0 & $\begin{array}{c}0.4 \\
(7.0)\end{array}$ & 0.0 & $\begin{array}{c}-0.1 \\
(0.1)\end{array}$ \\
\hline Ophthalmologist & 5.4 & $\begin{array}{c}0.9 \\
(0.7)\end{array}$ & $\begin{array}{c}6.4 \\
(4.5)\end{array}$ & 6.4 & $\begin{array}{c}-0.2 \\
(10.4)\end{array}$ & 5.1 & $\begin{array}{c}8.1 \\
(5.1)\end{array}$ \\
\hline ENT specialist & 5.1 & $\begin{array}{l}1.8^{* *} \\
(0.8)\end{array}$ & $\begin{array}{c}12.3^{* *} \\
(5.8)\end{array}$ & 4.7 & $\begin{array}{c}19.3^{*} \\
(11.1)\end{array}$ & 5.3 & $\begin{array}{c}9.7 \\
(6.9)\end{array}$ \\
\hline Orthopaedist & 1.3 & $\begin{array}{c}0.1 \\
(0.3)\end{array}$ & $\begin{array}{c}0.3 \\
(2.2)\end{array}$ & 1.1 & $\begin{array}{c}3.9 \\
(4.2)\end{array}$ & 1.4 & $\begin{array}{l}-0.8 \\
(2.7)\end{array}$ \\
\hline Laboratory & 5.1 & $\begin{array}{c}0.1 \\
(0.8)\end{array}$ & $\begin{array}{c}0.7 \\
(5.8)\end{array}$ & 3.8 & $\begin{array}{c}5.8 \\
(9.2)\end{array}$ & 5.5 & $\begin{array}{l}-1.6 \\
(7.2)\end{array}$ \\
\hline Radi & 2.9 & $\begin{array}{c}0.2 \\
(0.6)\end{array}$ & $\begin{array}{c}1.5 \\
(4.0)\end{array}$ & 2.3 & $\begin{array}{l}12.5^{*} \\
(7.3)\end{array}$ & 3.1 & $\begin{array}{c}-2.4 \\
(4.9)\end{array}$ \\
\hline Jo. of observatio &, 51 & & & 2,34 & & $7,1^{\prime}$ & \\
\hline \multicolumn{8}{|c|}{$\begin{array}{l}\text { Notes: This table summarizes estimation results of the effect of screening participation on the scope } \\
\text { of intervention captured by spending on medical specialists borne by referrals and aggregated over the } \\
\text { children's age range between } 18 \text { and } 54 \text { months. Each entry reflects a separate regression, in which the } \\
\text { dependent variable is indicated on the very left. The method of estimation is two-stage least squares } \\
\text { based on the model described by eqs. (3) and (4) and robust standard errors are reported in parentheses, } \\
* p<0.1, * *<<0.05, \text { and } * * * * 0.01 \text {. Columns (1) to (3) provide the mean of the dependent variable, } \\
\text { the intention-to-treat effect (ITT, based on the reduced form) and the local average treatment effect } \\
\text { (LATE, based on the second stage) for the full sample. Columns (4) and (5) provide the mean of } \\
\text { the dependent variable and the LATE for the sample of low socio-economic status (SES) preschoolers. } \\
\text { Columns (6) and ( }(7) \text { provide the mean of the dependent variable and the LATE for the sample of } \\
\text { high SES preschoolers. The preschooler's SES is defined according to his or her mother's educational } \\
\text { attainment at birth. If the mother's highest degree is compulsory schooling, then the preschooler is } \\
\text { defined as low SES. }\end{array}$} \\
\hline
\end{tabular}




\section{Web Appendix}

This Web Appendix (not for publication) provides additional material discussed in the unpublished manuscript 'The Cost-Effectiveness of Developmental Screenings: Evidence from a Nationwide Programme' by Martin Halla, Gerald J. Pruckner, and Thomas Schober. 
Table A.1: Robustness Check: Effect of Participation in at Least Two Examinations on Scope of Intervention

\begin{tabular}{|c|c|c|c|c|c|c|c|}
\hline & \multicolumn{3}{|c|}{$\begin{array}{l}\text { Full SAMPle } \\
\text { OF Preschoolers }\end{array}$} & \multicolumn{2}{|c|}{$\begin{array}{c}\text { LOW SES } \\
\text { PRESCHOOLERS }\end{array}$} & \multicolumn{2}{|c|}{$\begin{array}{c}\text { HIGH SES } \\
\text { PRESCHOOLERS }\end{array}$} \\
\hline & $\begin{array}{l}(1) \\
\text { Mean }\end{array}$ & $\begin{array}{l}(2) \\
\text { ITT }\end{array}$ & $\begin{array}{c}(3) \\
\text { LATE }\end{array}$ & $\begin{array}{c}(4) \\
\text { Mean }\end{array}$ & $\begin{array}{c}(5) \\
\text { LATE }\end{array}$ & $\begin{array}{c}(6) \\
\text { Mean }\end{array}$ & $\begin{array}{c}(7) \\
\text { LATE }\end{array}$ \\
\hline \multicolumn{8}{|c|}{$\begin{array}{l}\text { Aggregate Health Spending Categories } \\
\text { Between } 18 \text { And } 54 \text { Months of Age }\end{array}$} \\
\hline Outpatient medical care & 305.2 & $\begin{array}{c}11.0 \\
(10.3)\end{array}$ & $\begin{array}{c}78.5 \\
(70.1)\end{array}$ & 278.9 & $\begin{array}{c}295.7^{* * *} \\
(90.1)\end{array}$ & 313.7 & $\begin{array}{c}-51.7 \\
(105.9)\end{array}$ \\
\hline Medication & 64.8 & $\begin{array}{l}-6.2 \\
(4.1)\end{array}$ & $\begin{array}{l}-44.4 \\
(30.9)\end{array}$ & 63.5 & $\begin{array}{c}18.4 \\
(40.7)\end{array}$ & 65.3 & $\begin{array}{l}-86.1^{*} \\
(45.3)\end{array}$ \\
\hline Days in hospital & 1.9 & $\begin{array}{c}0.3 \\
(0.2)\end{array}$ & $\begin{array}{c}2.2 \\
(1.6)\end{array}$ & 2.6 & $\begin{array}{l}7.3^{*} \\
(4.0)\end{array}$ & 1.7 & $\begin{array}{l}-0.7 \\
(1.6)\end{array}$ \\
\hline \multicolumn{8}{|c|}{$\begin{array}{l}\text { AgGregated Spending on Medical Specialists } \\
\text { BETWEen } 18 \text { AND } 54 \text { Months of Age in Euro }\end{array}$} \\
\hline Paediatrician & 100.3 & $\begin{array}{c}11.6^{* *} \\
(5.5)\end{array}$ & $\begin{array}{l}82.9^{* *} \\
(35.3)\end{array}$ & 91.9 & $\begin{array}{c}174.4^{* * *} \\
(48.3)\end{array}$ & 103.0 & $\begin{array}{c}31.3 \\
(51.0)\end{array}$ \\
\hline General practitioner & 128.9 & $\begin{array}{l}-4.8 \\
(5.5)\end{array}$ & $\begin{array}{l}-34.6 \\
(40.4)\end{array}$ & 125.0 & $\begin{array}{c}41.9 \\
(53.2)\end{array}$ & 130.1 & $\begin{array}{l}-80.2 \\
(58.4)\end{array}$ \\
\hline Dentist & 11.8 & $\begin{array}{c}1.0 \\
(1.5)\end{array}$ & $\begin{array}{c}7.4 \\
(10.9)\end{array}$ & 9.9 & $\begin{array}{c}19.2 \\
(16.5)\end{array}$ & 12.4 & $\begin{array}{c}-0.1 \\
(14.5)\end{array}$ \\
\hline Ophthalmologist & 18.9 & $\begin{array}{l}3.0^{* *} \\
(1.3)\end{array}$ & $\begin{array}{c}21.5^{* *} \\
(9.1)\end{array}$ & 15.7 & $\begin{array}{c}3.2 \\
(12.2)\end{array}$ & 20.0 & $\begin{array}{l}30.1^{* *} \\
(13.0)\end{array}$ \\
\hline ENT specialist & 12.0 & $\begin{array}{c}1.1 \\
(1.6)\end{array}$ & $\begin{array}{c}7.6 \\
(11.4)\end{array}$ & 8.4 & $\begin{array}{l}27.3^{* *} \\
(12.8)\end{array}$ & 13.2 & $\begin{array}{c}-4.7 \\
(16.8)\end{array}$ \\
\hline Orthopaedist & 3.1 & $\begin{array}{l}0.9^{*} \\
(0.5)\end{array}$ & $\begin{array}{c}6.4 \\
(3.9)\end{array}$ & 2.3 & $\begin{array}{c}7.2 \\
(4.7)\end{array}$ & 3.4 & $\begin{array}{c}5.9 \\
(5.6)\end{array}$ \\
\hline Laboratory & 5.5 & $\begin{array}{l}-0.1 \\
(0.9)\end{array}$ & $\begin{array}{l}-0.4 \\
(6.2)\end{array}$ & 4.1 & $\begin{array}{c}2.8 \\
(6.9)\end{array}$ & 5.9 & $\begin{array}{l}-3.0 \\
(9.0)\end{array}$ \\
\hline Radiologist & 3.1 & $\begin{array}{c}0.4 \\
(0.6)\end{array}$ & $\begin{array}{c}2.7 \\
(4.2)\end{array}$ & 2.3 & $\begin{array}{l}9.4^{*} \\
(5.3)\end{array}$ & 3.3 & $\begin{array}{l}-1.4 \\
(6.0)\end{array}$ \\
\hline Number of observations & 9,516 & & & 2,346 & & 7,170 & \\
\hline
\end{tabular}

Notes: This table summarizes estimation results of the effect of participation in at least two examinations on the scope of intervention captured by different health spending categories aggregated over the children's age range between 18 and 54 months. Each entry reflects a separate regression, in which the dependent variable is indicated on the very left. The upper panel summarizes results for aggregate health spending categories, and the lower panel summarizes results for spending on medical specialists. The method of estimation is two-stage least squares based on the model described by eqs. (3) and (4), which includes covariates listed in Table 2 . Robust standard errors are reported in parentheses, ${ }^{*} p<0.1$, ${ }^{* *} p<0.05$, and ${ }^{* * *} p<0.01$. Columns (1) to (3) provide the mean of the dependent variable, the intention-to-treat effect (ITT, based on the reduced form) and the local average treatment effect (LATE, based on the second stage) for the full sample. Columns (4) and (5) provide the mean of the dependent variable and the LATE for the sample of low socio-economic status (SES) preschoolers. Columns (6) and (7) provide the mean of the dependent variable and the LATE for the sample of high SES preschoolers. The preschooler's SES is defined according to his or her mother's educational attainment at birth. If the mother's highest degree is compulsory schooling, then the preschooler is defined as low SES. 
Table A.2: Robustness Check: Effect of Number of Examinations on Scope of Intervention

\begin{tabular}{|c|c|c|c|c|c|c|c|}
\hline & \multicolumn{3}{|c|}{$\begin{array}{l}\text { FUll SAMPle } \\
\text { OF PRESCHOOLERS }\end{array}$} & \multicolumn{2}{|c|}{$\begin{array}{c}\text { LOW SES } \\
\text { PRESCHOOLERS }\end{array}$} & \multicolumn{2}{|c|}{$\begin{array}{c}\text { HIGH SES } \\
\text { PRESCHOOLERS }\end{array}$} \\
\hline & $\begin{array}{c}(1) \\
\text { Mean }\end{array}$ & $\begin{array}{l}(2) \\
\text { ITT }\end{array}$ & $\begin{array}{c}(3) \\
\text { LATE }\end{array}$ & $\begin{array}{c}(4) \\
\text { Mean }\end{array}$ & $\begin{array}{c}(5) \\
\text { LATE }\end{array}$ & $\begin{array}{c}(6) \\
\text { Mean }\end{array}$ & $\begin{array}{c}(7) \\
\text { LATE }\end{array}$ \\
\hline \multicolumn{8}{|c|}{$\begin{array}{l}\text { Aggregate Health Spending Categories } \\
\text { Between } 18 \text { and } 54 \text { Months of Age }\end{array}$} \\
\hline Outpatient medical care & 305.2 & $\begin{array}{l}11.0 \\
(10.3)\end{array}$ & $\begin{array}{c}30.6 \\
(27.2)\end{array}$ & 278.9 & $\begin{array}{c}114.9^{* * *} \\
(33.6)\end{array}$ & 313.7 & $\begin{array}{l}-20.2 \\
(41.4)\end{array}$ \\
\hline Medication & 64.8 & $\begin{array}{l}-6.2 \\
(4.1)\end{array}$ & $\begin{array}{l}-17.3 \\
(12.0)\end{array}$ & 63.5 & $\begin{array}{c}7.1 \\
(15.8)\end{array}$ & 65.3 & $\begin{array}{l}-33.6^{*} \\
(17.6)\end{array}$ \\
\hline Days in hospital & 1.9 & $\begin{array}{c}0.3 \\
(0.2)\end{array}$ & $\begin{array}{l}0.9 \\
(0.6)\end{array}$ & 2.6 & $\begin{array}{l}2.8^{*} \\
(1.5)\end{array}$ & 1.7 & $\begin{array}{l}-0.3 \\
(0.6)\end{array}$ \\
\hline \multicolumn{8}{|c|}{$\begin{array}{l}\text { Aggregated Spending on Medical Specialists } \\
\text { Between } 18 \text { and } 54 \text { Months of Age in euro }\end{array}$} \\
\hline Paediatrician & 100.3 & $\begin{array}{c}11.6^{* *} \\
(5.5)\end{array}$ & $\begin{array}{l}32.3^{* *} \\
(13.6)\end{array}$ & 91.9 & $\begin{array}{c}67.8^{* * *} \\
(18.1)\end{array}$ & 103.0 & $\begin{array}{c}12.2 \\
(19.9)\end{array}$ \\
\hline General practitioner & 128.9 & $\begin{array}{l}-4.8 \\
(5.5)\end{array}$ & $\begin{array}{l}-13.5 \\
(15.7)\end{array}$ & 125.0 & $\begin{array}{c}16.3 \\
(20.6)\end{array}$ & 130.1 & $\begin{array}{l}-31.3 \\
(22.8)\end{array}$ \\
\hline Dentist & 11.8 & $\begin{array}{c}1.0 \\
(1.5)\end{array}$ & $\begin{array}{c}2.9 \\
(4.3)\end{array}$ & 9.9 & $\begin{array}{c}7.5 \\
(6.4)\end{array}$ & 12.4 & $\begin{array}{l}-0.0 \\
(5.7)\end{array}$ \\
\hline Ophthalmologist & 18.9 & $\begin{array}{l}3.0^{* *} \\
(1.3)\end{array}$ & $\begin{array}{l}8.4^{* *} \\
(3.5)\end{array}$ & 15.7 & $\begin{array}{c}1.2 \\
(4.7)\end{array}$ & 20.0 & $\begin{array}{c}11.8^{* *} \\
(4.9)\end{array}$ \\
\hline ENT specialist & 12.0 & $\begin{array}{c}1.1 \\
(1.6)\end{array}$ & $\begin{array}{c}2.9 \\
(4.5)\end{array}$ & 8.4 & $\begin{array}{c}10.6^{* *} \\
(4.9)\end{array}$ & 13.2 & $\begin{array}{l}-1.8 \\
(6.6)\end{array}$ \\
\hline Orthopaedist & 3.1 & $\begin{array}{c}0.9^{*} \\
(0.5)\end{array}$ & $\begin{array}{c}2.5 \\
(1.5)\end{array}$ & 2.3 & $\begin{array}{c}2.8 \\
(1.8)\end{array}$ & 3.4 & $\begin{array}{c}2.3 \\
(2.2)\end{array}$ \\
\hline Laboratory & 5.5 & $\begin{array}{l}-0.1 \\
(0.9)\end{array}$ & $\begin{array}{l}-0.2 \\
(2.4)\end{array}$ & 4.1 & $\begin{array}{c}1.1 \\
(2.7)\end{array}$ & 5.9 & $\begin{array}{l}-1.2 \\
(3.5)\end{array}$ \\
\hline Radiologist & 3.1 & $\begin{array}{c}0.4 \\
(0.6)\end{array}$ & $\begin{array}{l}1.0 \\
(1.6)\end{array}$ & 2.3 & $\begin{array}{l}3.7^{*} \\
(2.0)\end{array}$ & 3.3 & $\begin{array}{l}-0.5 \\
(2.3)\end{array}$ \\
\hline Number of observations & 9,516 & & & 2,346 & & 7,170 & \\
\hline \multicolumn{8}{|c|}{$\begin{array}{l}\text { Notes: This table summarizes estimation results of the effect of the number of screenings in which the child } \\
\text { participated on the scope of intervention captured by different health spending categories aggregated over the } \\
\text { children's age range between } 18 \text { and } 54 \text { months. Each entry reflects a separate regression, in which the dependent } \\
\text { variable is indicated on the very left. The upper panel summarizes results for aggregate health spending cate- } \\
\text { gories, and the lower panel summarizes results for spending on medical specialists. The method of estimation } \\
\text { is two-stage least squares based on the model described by eqs. (3) and }(4) \text {, which includes covariates listed in } \\
\text { Table } 2 \text {. Robust standard errors are reported in parentheses, }{ }^{*} p<0.1,{ }^{* *} p<0.05 \text {, and }{ }^{* * *} p<0.01 \text {. Columns } \\
\text { (1) to (3) provide the mean of the dependent variable, the intention-to-treat effect (ITT, based on the reduced } \\
\text { form) and the local average treatment effect (LATE, based on the second stage) for the full sample. Columns }(4) \\
\text { and (5) provide the mean of the dependent variable and the LATE for the sample of low socio-economic status } \\
\text { (SES) preschoolers. Columns (6) and (7) provide the mean of the dependent variable and the LATE for the } \\
\text { sample of high SES preschoolers. The preschooler's SES is defined according to his or her mother's educational } \\
\text { attainment at birth. If the mother's highest degree is compulsory schooling, then the preschooler is defined as } \\
\text { low SES. }\end{array}$} \\
\hline
\end{tabular}


Table A.3: Robustness Check: Effect of Participation in at least Two Examinations on Long-run Healthcare Costs

\begin{tabular}{|c|c|c|c|c|c|c|c|}
\hline & \multicolumn{3}{|c|}{$\begin{array}{c}\text { Full SAMPle } \\
\text { OF PRESCHOOLERS }\end{array}$} & \multicolumn{2}{|c|}{$\begin{array}{c}\text { LOW SES } \\
\text { PRESCHOOLERS }\end{array}$} & \multicolumn{2}{|c|}{$\begin{array}{c}\text { High SES } \\
\text { PRESCHOOLERS }\end{array}$} \\
\hline & $\begin{array}{l}(1) \\
\text { Mean }\end{array}$ & $\begin{array}{l}(2) \\
\text { ITT }\end{array}$ & $\begin{array}{c}(3) \\
\text { LATE }\end{array}$ & $\begin{array}{c}(4) \\
\text { Mean }\end{array}$ & $\begin{array}{c}(5) \\
\text { LATE }\end{array}$ & $\begin{array}{c}(6) \\
\text { Mean }\end{array}$ & $\begin{array}{c}(7) \\
\text { LATE }\end{array}$ \\
\hline \multicolumn{8}{|c|}{$\begin{array}{l}\text { Aggregate Health Spending Categories } \\
\text { Between } 6 \text { And } 10.5 \text { Years of Age }\end{array}$} \\
\hline Outpatient medical care & 969.3 & $\begin{array}{l}-23.0 \\
(41.3)\end{array}$ & $\begin{array}{l}-164.9 \\
(298.3)\end{array}$ & 915.5 & $\begin{array}{l}-427.2 \\
(415.1)\end{array}$ & 986.9 & $\begin{array}{c}-20.3 \\
(407.4)\end{array}$ \\
\hline Medication & 151.4 & $\begin{array}{l}-13.4 \\
(14.1)\end{array}$ & $\begin{array}{l}-95.7 \\
(102.1)\end{array}$ & 147.5 & $\begin{array}{c}-95.4 \\
(122.2)\end{array}$ & 152.6 & $\begin{array}{l}-104.9 \\
(145.3)\end{array}$ \\
\hline Days in hospital & 2.2 & $\begin{array}{c}0.8 \\
(0.9)\end{array}$ & $\begin{array}{c}5.5 \\
(6.3)\end{array}$ & 3.6 & $\begin{array}{c}6.0 \\
(16.3)\end{array}$ & 1.8 & $\begin{array}{c}3.2 \\
(5.3)\end{array}$ \\
\hline
\end{tabular}

Aggregated Spending on Medical Specialists Between 6 AND 10.5 Years of Age in euro

\begin{tabular}{lccccccc} 
Paediatrician & 69.4 & 2.2 & 16.1 & 74.2 & 28.8 & 67.8 & 6.4 \\
& & $(5.3)$ & $(37.4)$ & & $(52.9)$ & & $(51.1)$ \\
General practitioner & 198.1 & $-11.1^{*}$ & -79.3 & 208.3 & $-126.5^{*}$ & 194.7 & -55.3 \\
& & $(6.6)$ & $(48.7)$ & & $(71.6)$ & & $(65.3)$ \\
Dentist & 359.3 & 0.6 & 4.4 & 294.4 & -5.8 & 380.5 & 27.8 \\
& & $(22.9)$ & $(164.0)$ & & $(189.5)$ & & $(235.5)$ \\
Ophthalmologist & 43.7 & 0.6 & 4.6 & 38.9 & -8.9 & 45.3 & 11.5 \\
& & $(2.5)$ & $(17.8)$ & & $(25.2)$ & & $(24.2)$ \\
ENT specialist & 28.1 & 0.1 & 1.0 & 25.4 & 4.2 & 28.9 & -0.7 \\
& & $(2.8)$ & $(20.1)$ & & $(28.4)$ & & $(27.2)$ \\
Orthopaedist & 5.3 & 0.1 & 0.7 & 4.5 & -0.2 & 5.5 & 0.8 \\
& & $(0.8)$ & $(5.4)$ & & $(7.1)$ & & $(7.5)$ \\
Laboratory & 9.7 & 1.5 & 10.7 & 9.2 & -4.1 & 9.8 & 17.9 \\
\multirow{2}{*}{ Radiologist } & & $(1.2)$ & $(8.3)$ & & $(11.0)$ & & $(11.9)$ \\
& 9.0 & -1.1 & -7.7 & 9.1 & -6.3 & 9.0 & -8.9 \\
& & $(1.1)$ & $(8.2)$ & & $(12.2)$ & & $(11.0)$ \\
\hline Number of observations & 9,516 & & & 2,346 & & 7,170 & \\
\hline
\end{tabular}

Notes: This table summarizes estimation results of the effect of participation in at least two examinations on long-run healthcare costs captured by different health spending categories aggregated over the children's age range between 6 and 10.5 years. Each entry reflects a separate regression, in which the dependent variable is indicated on the very left. The upper panel summarizes results for aggregate health spending categories, and the lower panel summarizes results for spending on medical specialists. The method of estimation is two-stage least squares based on the model described by eqs. (3) and (4), which includes covariates listed in Table 2 Robust standard errors are reported in parentheses, ${ }^{*} p<0.1,{ }^{* *} p<0.05$, and ${ }^{* * *} p<0.01$. Columns (1) to (3) provide the mean of the dependent variable, the intention-to-treat effect (ITT, based on the reduced form) and the local average treatment effect (LATE, based on the second stage) for the full sample. Columns (4) and (5) provide the mean of the dependent variable and the LATE for the sample of low socio-economic status (SES) preschoolers. Columns (6) and (7) provide the mean of the dependent variable and the LATE for the sample of high SES preschoolers. The preschooler's SES is defined according to his or her mother's educational attainment at birth. If the mother's highest degree is compulsory schooling, then the preschooler is defined as low SES. 
Table A.4: Robustness Check: Effect of Number of Examinations on Long-run Healthcare Costs

\begin{tabular}{|c|c|c|c|c|c|c|c|}
\hline & \multicolumn{3}{|c|}{$\begin{array}{l}\text { Full Sample } \\
\text { OF Preschoolers }\end{array}$} & \multicolumn{2}{|c|}{$\begin{array}{c}\text { LOW SES } \\
\text { PreschoOlers }\end{array}$} & \multicolumn{2}{|c|}{$\begin{array}{c}\text { High SES } \\
\text { PRESCHOOLERS }\end{array}$} \\
\hline & $\begin{array}{c}(1) \\
\text { Mean }\end{array}$ & $\begin{array}{l}(2) \\
\text { ITT }\end{array}$ & $\begin{array}{c}(3) \\
\text { LATE }\end{array}$ & $\begin{array}{c}(4) \\
\text { Mean }\end{array}$ & $\begin{array}{c}(5) \\
\text { LATE }\end{array}$ & $\begin{array}{c}(6) \\
\text { Mean }\end{array}$ & $\begin{array}{c}(7) \\
\text { LATE }\end{array}$ \\
\hline \multicolumn{8}{|c|}{$\begin{array}{l}\text { Aggregate Health Spending Categories } \\
\text { Between } 6 \text { And } 10.5 \text { Years of Age }\end{array}$} \\
\hline Outpatient medical care & 969.3 & $\begin{array}{l}-23.0 \\
(41.3)\end{array}$ & $\begin{array}{c}-64.2 \\
(116.2)\end{array}$ & 915.5 & $\begin{array}{l}-166.0 \\
(161.1)\end{array}$ & 986.9 & $\begin{array}{c}-7.9 \\
(159.0)\end{array}$ \\
\hline Medication & 151.4 & $\begin{array}{l}-13.4 \\
(14.1)\end{array}$ & $\begin{array}{l}-37.3 \\
(39.7)\end{array}$ & 147.5 & $\begin{array}{l}-37.1 \\
(47.4)\end{array}$ & 152.6 & $\begin{array}{l}-41.0 \\
(56.6)\end{array}$ \\
\hline Days in hospital & 2.2 & $\begin{array}{c}0.8 \\
(0.9)\end{array}$ & $\begin{array}{c}2.2 \\
(2.4)\end{array}$ & 3.6 & $\begin{array}{c}2.3 \\
(6.3)\end{array}$ & 1.8 & $\begin{array}{c}1.2 \\
(2.1)\end{array}$ \\
\hline \multicolumn{8}{|c|}{$\begin{array}{l}\text { AgGregated Spending on Medical Specialists } \\
\text { Between } 6 \text { And } 10.5 \text { Years of Age }\end{array}$} \\
\hline Paediatrician & 69.4 & $\begin{array}{c}2.2 \\
(5.3)\end{array}$ & $\begin{array}{c}6.3 \\
(14.6)\end{array}$ & 74.2 & $\begin{array}{c}11.2 \\
(20.5)\end{array}$ & 67.8 & $\begin{array}{c}2.5 \\
(20.0)\end{array}$ \\
\hline General practitioner & 198.1 & $\begin{array}{r}-11.1^{*} \\
(6.6)\end{array}$ & $\begin{array}{l}-30.9 \\
(18.9)\end{array}$ & 208.3 & $\begin{array}{l}-49.1^{*} \\
(27.5)\end{array}$ & 194.7 & $\begin{array}{l}-21.6 \\
(25.5)\end{array}$ \\
\hline Dentist & 359.3 & $\begin{array}{c}0.6 \\
(22.9)\end{array}$ & $\begin{array}{c}1.7 \\
(63.9)\end{array}$ & 294.4 & $\begin{array}{c}-2.3 \\
(73.6)\end{array}$ & 380.5 & $\begin{array}{c}10.9 \\
(91.9)\end{array}$ \\
\hline Ophthalmologist & 43.7 & $\begin{array}{l}0.6 \\
(2.5)\end{array}$ & $\begin{array}{c}1.8 \\
(6.9)\end{array}$ & 38.9 & $\begin{array}{c}-3.4 \\
(9.8)\end{array}$ & 45.3 & $\begin{array}{c}4.5 \\
(9.4)\end{array}$ \\
\hline ENT specialist & 28.1 & $\begin{array}{c}0.1 \\
(2.8)\end{array}$ & $\begin{array}{c}0.4 \\
(7.8)\end{array}$ & 25.4 & $\begin{array}{c}1.7 \\
(11.0)\end{array}$ & 28.9 & $\begin{array}{c}-0.3 \\
(10.6)\end{array}$ \\
\hline Orthopaedist & 5.3 & $\begin{array}{c}0.1 \\
(0.8)\end{array}$ & $\begin{array}{c}0.3 \\
(2.1)\end{array}$ & 4.5 & $\begin{array}{l}-0.1 \\
(2.7)\end{array}$ & 5.5 & $\begin{array}{c}0.3 \\
(2.9)\end{array}$ \\
\hline Laboratory & 9.7 & $\begin{array}{c}1.5 \\
(1.2)\end{array}$ & $\begin{array}{c}4.2 \\
(3.2)\end{array}$ & 9.2 & $\begin{array}{l}-1.6 \\
(4.3)\end{array}$ & 9.8 & $\begin{array}{c}7.0 \\
(4.6)\end{array}$ \\
\hline Radiologist & 9.0 & $\begin{array}{l}-1.1 \\
(1.1) \\
\end{array}$ & $\begin{array}{l}-3.0 \\
(3.2)\end{array}$ & 9.1 & $\begin{array}{l}-2.4 \\
(4.7)\end{array}$ & 9.0 & $\begin{array}{l}-3.5 \\
(4.3)\end{array}$ \\
\hline Number of observations & 9,516 & & & 2,346 & & 7,170 & \\
\hline \multicolumn{8}{|c|}{$\begin{array}{l}\text { Notes: This table summarizes estimation results of the effect of the number of screenings in which the child } \\
\text { participated in long-run healthcare costs captured by different health spending categories aggregated over the } \\
\text { children's age range between } 6 \text { and } 10.5 \text { years. Each entry reflects a separate regression, in which the dependent } \\
\text { variable is indicated on the very left. The upper panel summarizes results for aggregate health spending cate- } \\
\text { gories, and the lower panel summarizes results for spending on medical specialists. The method of estimation } \\
\text { is two-stage least squares based on the model described by eqs. (3) and }(4) \text {, which includes covariates listed in } \\
\text { Table } 2 \text {. Robust standard errors are reported in parentheses, }{ }^{*} p<0.1,{ }^{* *} p<0.05 \text {, and }{ }^{* * *} p<0.01 \text {. Columns } \\
\text { (1) to (3) provide the mean of the dependent variable, the intention-to-treat effect (ITT, based on the reduced } \\
\text { form) and the local average treatment effect (LATE, based on the second stage) for the full sample. Columns } \\
\text { (4) and (5) provide the mean of the dependent variable and the LATE for the sample of low socio-economic } \\
\text { status (SES) preschoolers. Columns (6) and ( } 7 \text { ) provide the mean of the dependent variable and the LATE } \\
\text { for the sample of higher SES preschoolers. The preschooler's SES is defined according to his or her mother's } \\
\text { educational attainment at birth. If the mother's highest degree is compulsory schooling, then the preschooler is } \\
\text { defined as low SES. }\end{array}$} \\
\hline
\end{tabular}

